\title{
The Strategies and Structure of
}

\section{Gossip in the Speech of Adolescent} and Adult Egyptians and Native

\author{
English Speakers
}

Dr. Marwa Mohamed Khamis El-Zouka

English Department - Faculty of Arts

Alexandria University 


\section{Introduction}

Everyday speech abounds in a number of conversational features including gossip that people indulge in, mostly on a daily basis, to exchange information and make evaluative comments about nonpresent others as well as events. Indeed, gossip is an everyday speech event with which we are inundated most of the time. This is indicated by Dunbar (2004: 105) who holds that gossip "accounts for approximately $65 \%$ of speaking time, with only limited variation due to age and gender." Also Emler (as cited in Grosser, Lopez-Kidwell \& Labianca, 2010: 178) maintains that two thirds of daily conversations include talk about absent parties. Gossip is also a ubiquitous activity practiced worldwide and prevalent in all cultures as indicated by Holland (1996: 200) who holds that "gossip appears to be universal among cultures as well as among individuals." Thus, this important social phenomenon has received attention due to its universality and the role it plays in creating social bonding between individuals and groups. 


\section{Aims of the Study}

Gossip is a collaborative and furtive speech event that takes place among friends, rather than strangers, and involves evaluative talk about events or absent people. Indeed, "to gossip, one must be disinclined to make the statement in the presence of the subject of the gossip" (Cuonzo, 2008: 131). That furtiveness is one of the main characteristics of gossip is expressed by Holland (1996: 204-205) as follows:

The following characteristics are shared by peeping and gossiping: they take as their objects persons rather than things, they occur behind the subject's back, they are not guided by concern for the subject, they would cease if the subject entered, they focus on personal features of the subject, and they are pleasurable for the agent.

As mentioned above, gossip is usually evaluative. This evaluative nature of gossip results from the failure of the subject of gossip to adhere to what is considered appropriate or acceptable behavior (Eggins \& Slade, 1997: 282). Besides having an evaluative quality, gossip also has a "distinctive and characteristic linguistic structure" (Eggins \& Slade, 1997: 274). Because gossip 
is a collaborative activity, participants in a gossip episode usually "co-construct the gossip" (Eggins \& Slade, 1997: 276). They also indicate participation in the gossip episode by exchanging information about the absent person and commenting on what is said using various linguistic strategies. Thus, the purpose of the present study is twofold. Firstly, it attempts to examine the impact of age on the structure and strategies used by adolescent and adult Egyptians and native English speakers when gossiping. Secondly, it seeks to determine the similarities and/or differences in the strategies of gossip found in the speech of adolescent and adult Egyptian and native English speakers.

\section{Data and Methodology of the Study}

The data analyzed in this paper is derived from 20 conversations that were audio-recorded over a period of two months. The duration of every conversation is about 20 to 30 minutes, yielding around eight hours of conversational data. The recorded conversations are equally divided between adolescents and adults, whether Egyptians or native English speakers. Within each age group, the conversations are also equally 
divided between Egyptians and native English speakers. The data has been collected from various places, namely the Bibliotheca Alexandrina, social clubs in Alexandria, the TAFL (Teaching Arabic as a Foreign Language) Center in Alexandria, the English Department in the Faculty of Arts, Alexandria University, as well as Khan El-Khalili in Cairo and aboard a Nile cruiser.

Adolescent participants in this study are in the 1723 years age bracket. The total number of adolescent participants who were recorded is 50 (25 Egyptians and 25 native English speakers). 60 adults (30 Egyptians and 30 native English speakers) participated in this study. They range in age from 35 to 50. Native English speaking participants, whether adolescent or adult, are American and British. All participants have similar educational and socioeconomic backgrounds; adolescent Egyptians and native English speakers, are university students and come from middle-class families while adult participants, whether Egyptians or native English speakers, hold different positions: university staff members, housewives, managers, teachers, and accountants. Since spontaneous speech has to be recorded to ensure obtaining naturally-occurring data 
and to avoid the observer's paradox, which refers to "the problem of observing how people speak when they are not being observed" (Labov, 1972: 256), participants' conversations were recorded without their awareness. However, after recording the conversations, participants were told that they were recorded and that the purpose of recording their conversations was to study some aspects of the conversational behavior of their age group. Participants then listened to the recordings and their consent to use the data was obtained. They were assured that their identities would be concealed and of the confidential treatment of the data. It is for this reason that all the names in the examples given in the analysis are pseudonyms.

After recording the conversations, the data was transcribed by the researcher (see Appendix A for transcription conventions). Instances of talk in which speakers evaluated, whether positively or negatively, the character or behavior of non-present parties have been identified and analyzed. Appendix $B$ includes transcripts of some extracts of some of the recorded conversations. These extracts are included in this 
appendix because the gossip episodes in them are quite significant.

In analyzing the data, the strategies and structure of gossip are examined in the speech of adolescent and adult Egyptians and native English speakers. Throughout the study, illustrative examples from the data are provided and explained.

\section{Review of Literature}

It is a widely held belief that gossip is a speech style most commonly engaged in by women. This belief is further supported by the etymology of the word which is "derived from the Old English 'godsibb' meaning grandparent, which came to be applied to familiar friends, but especially a woman's female friends [who were] present at the birth of a child" (Johnson, 1994: 153) and "idly chattered among themselves" (Rosnow \& Fine as cited in Grosser, Lopez-Kidwell, \& Labianca, 2010: 179). Thus, gossip came to be attributed to "women's talk" (Brown, 1990; Caotes, 1988; Eggins \& Slade, 1997; Jones, 1980) and much research also underpins the association between gossip and women (Eder \& Enke, 1991; Goodwin, 1980; 
Kuttler, Parker, \& La Greca, 2002; Rysman, 1977).This view is further supported by Deborah Jones' definition of gossip as:

A way of talking between women in their roles as women, intimate in style, personal and domestic in topic and setting, a female cultural event which springs from and perpetuates the restrictions of the female role, but also gives the comfort of validation (Jones as cited in Johnson, 1994: 146).

This quote shows that gossip is a typical female speech style that women resort to because they are excluded from the public domain. Thus, gossip "serves not only to provide comfort and mutual support within the group, it may also offer the opportunity to context oppression" (Johnson, 1994: 146).

The gender of gossip has also been considered a crucial factor in considering a certain piece of talk to be gossip. For example, when referring to women, gossip is referred to as "idle talk", "small talk", and "chit-chat", and as "schmoozing", "networking", "shop talk" and as "shooting the breeze" and "killing some time together" when referring to men. Therefore, some males deny any association with gossip (Fine \& Rosnow as cited in 
Foster, 2003: 4; Rosnow as cited in Hambaugh, 2011: 15).

Due to the negative stereotype that gossip is an activity that is characteristic of female, rather than, male speech, researchers have attempted to define the term "gossip" to examine the nature of this phenomenon. For instance, Tebbutt and Marchington (1997: 716) provide a definition of the term as "talk about common acquaintances, either factual or fabricated." Eggins and Slade (1997: 276) also define the term in question as a genre of talk that "involves sharing opinions and judgments about a person's behavior or physical attributes, and by doing so implicitly asserting appropriate behavior or defining a physical norm" Finally, Nevo, Nevo, and Derech-Zehavi (1993: 230) define the term as "verbal and written communication with no obvious conscious purpose regarding the personal matters of a third party."

In the above definitions, it seems that, regardless of its content, the defining feature of gossip is the exchange of information about a non-present third party. In other words, authors agree that the absence of a third party is a requirement for the occurrence of 
gossip. However, all these definitions lack an evaluative component expressed by Eder and Enke (1991: 494) in their definition of "gossip" as "evaluative talk about a person who is not present." Foster (2004: 83) also defines "gossip" as "the exchange of personal information (positive or negative) in an evaluative way (positive or negative) about absent third parties." Moreover, DiFonzo and Bordia (2007: 19) define "gossip" as "evaluative social talk about persons, usually not present, arising in the context of social networks."

What all the above definitions have in common is their focus on people although the concept of gossip can also include an exchange of value-laden information about circumstances, events or objects, and not just people. Furthermore, the last three definitions highlight the importance of the evaluative component in the study of gossip. This idea is also expressed by Foster (2004: 82) who holds that:

Most exchanges of personal news carry with them some evaluative meaning implicit in the shared tacit knowledge, histories, and cultural norms of the conversationalists. Consequently, some theoretical social functions of gossip...are such that they would 
be effectively eviscerated if the evaluative component were not an ingredient of the genre.

In the present study, Foster's definition is adopted because it explicitly states the fact that the evaluative component can either be negative or positive. This view challenges the belief that gossip is an activity that is of a negative valence only. Indeed, researchers have shown that gossip does not always have to be negative. For example, Ben-Ze'ev (1994: 23) holds that "Contrary to its popular reputation, gossip is not basically concerned with detraction, slander, or character assassination. Negative information may be remembered better, and hence the illusory impression of its dominance."

Blum-Kulka (as cited in Jaworski \& Coupland, 2005: 668) stresses the positive side of gossip and shows that it has "humanizing functions" because indulging in speech about other people forms an experience and helps build relationships by sharing and exchanging information with others. Thus, we become human. Dunbar (1992: 31) also asserts the existence of a positive evaluative component in gossip and highlights the role it plays in establishing social relationships. He argues that: 
By talking to one person, we can find out a great deal about how others are likely to behave, how we should react to them when we actually meet them, and what kinds of relationships they have with the third parties. All these things allow us to coordinate our social relationships within a group more effectively.

Besides studying the nature of gossip as a speech activity, researchers have also attempted to determine its social, individual and group functions. Socially, it has been found that gossip serves four functions: information, entertainment, influence and friendship (or intimacy) (Foster, 2003:7). As for the first function, gossip is considered an important mechanism of information exchange and is described as a vital means of gathering or disseminating information. Moreover, Bergmann (as cited in Foster, 2003: 8) holds that the unequal distribution of knowledge gives value to the information spread via gossip.

In terms of entertainment, Spacks (1982: 31) holds that "It is the sheer fun which for most gossipers explains their involvement." Thus, the entertainment and recreational values of the gossipers can be the only reason for the occurrence of gossip. These values also 
occur outside the actual exchange. In other words, whether gossip takes place before, during, or after a speech event, it provides important stimulation to break the monotony of life (Foster, 2004: 85).

The influence function of gossip refers to three main points. First, gossip is considered an effective social mechanism as it could aim either at reforming or stigmatizing a sinner (Cox as cited in Foster, 2004: 86). Second, listening to gossip helps one know how to behave, what to do and what not to do because the "corporate culture" in an organization or a group relies on expressing norms and mores by means of various forms, the most common of which is gossip. Thus, cultural learning is a primary function of gossip as it enhances social comparison and social understanding (Foster, 2004: 86). Third, for gossip to be influential, norms for behavior must be agreed upon. Therefore, although susceptibility to the influence of gossip varies from one person to another, people conform to the accepted norms to protect their membership in their groups since deviating from established norms will "be circulated in the form of gossip" (Foster, 2004: 86-87). 
Gossip's friendship or intimacy function refers to the role of gossip in establishing dyadic and group boundaries because it is more likely to take place between friends, rather than strangers since gossiping signals the gossipers' confidence in each other, their certainty of the security of the "dyadic boundary" as well as their understanding of the subtleties of the gossip. Therefore, gossip helps cement relationships and distinguish insiders from outsiders (Foster, 2003: 9).

Establishing and cementing relations at the dyadic and group level is closely related to the individual and group functions of gossip. Indeed, gossip can bring considerable benefits to individuals and groups. At the individual level, exchanging information through gossip can provide individuals with relief from feelings of tension and anxiety (Michelson, van Iterson, \& Waddington, 2010: 375). Gossip can also be an attention-seeking activity that aims to advance one's self-interest and self-image via social comparison and discrediting others (Michelson et al., 2010: 373). In a similar vein, Holland (1996: 201) holds that individuals gossip "to improve their standing by showing that they measure up favorably to accepted standards." In 
addition, gossip can help individuals gain status and power over others because when it operates at the individual level, gossip is considered a mechanism for manipulating information. In this respect, gossipers learn to spread information which they believe can be used to gain status. This is because by assessing the behavior of others, gossipers show their positions with respect to the person being gossiped about (Pilkington, 1998: 255; Warber, 2004: 6).

At the group level, the circulation of information via gossip fosters social bonds among the participants and helps reinforce group norms, thereby enabling cultural learning (Michelson et al., 2010: 375). Gossip also strengthens group identity and creates group cohesion by "providing a sense of belonging to a limited circle" (Holland, 1996: 201). Furthermore, gossip signifies group membership, establishes group boundaries, and defines group norms by endorsing behavior approved by the group and deemed acceptable, and thus exclude those who breach established norms (Hambaugh, 2011: 23; Jaworski \& Coupland, 2005: 668; Warber, 2004: 6). 
The diversity of definitions and functions of gossip shows that this speech activity is prevalent in everyday conversations. Literature also indicates that there are different types of gossip that have been assigned different terms such as critical and uncritical, information sharing and judgmental, blame and praise gossip, good gossip and bad gossip, and positive and negative gossip (Michelson et al., 2010: 378).

According to Foster (2004: 82), positive gossip involves the exchange of favorable information that is to the benefit of the gossipee while negative gossip involves the exchange of less favorable information. Moreover, while positive gossip facilitates the formation of a group, establishes the social group rules for members to abide by, and tends to enhance a person's reputation, negative gossip acts as a punishment for behavior that transgresses established group norms and appropriate group behavior, and can tarnish a person's reputation (Hambaugh, 2011: 23, 28-29; Kurland \& Pelled, 2000: 430).

A further distinction is made between workrelated (professional) and non-work-related (social) gossip. The former indicates "the degree to which gossip 
is focused on a subject's work life, such as job performance, career progress, relationships with other organizational members, and general behavior in the workplace" (Kurland \& Pelled, 2000: 430). Non-workrelated (social) gossip, on the other hand, refers to gossip about social topics concerning, but not limited to, personal relationships. The choice of topics of discussion in gossip depends on the gender of gossipers. Research shows that topics of men's gossip are in line with traditional male gender roles. Thus, men gossip about impersonal matters, sports, getting work, and learning a trade (Warber, 2004: 9). Moreover, men tend to discuss political rather than personal relationships, and if they talk about personal matters, this is more likely to be brief and devoid of details (Tannen, 1990: 101). Women, on the other hand, are interested in the details of personal lives and focus on information about family and friends (Hambaugh, 2011: 48; Tannen, 1990: 110). Thus, according to Holland (1996: 198), "topics of discussion in gossip are of a personal, though not necessarily a private nature."

The present study adopts the structure of gossip proposed by Eder and Enke (1991) who examined the 
structure of adolescent gossip due to their belief that analyzing "the structure of gossip among adolescents may help explain the strong tendency in gossip episodes toward negative evaluation and consensus" (Eder \& Enke, 1991: 495). Eder and Enke's structure of a gossip episode is shown in figure (1): 


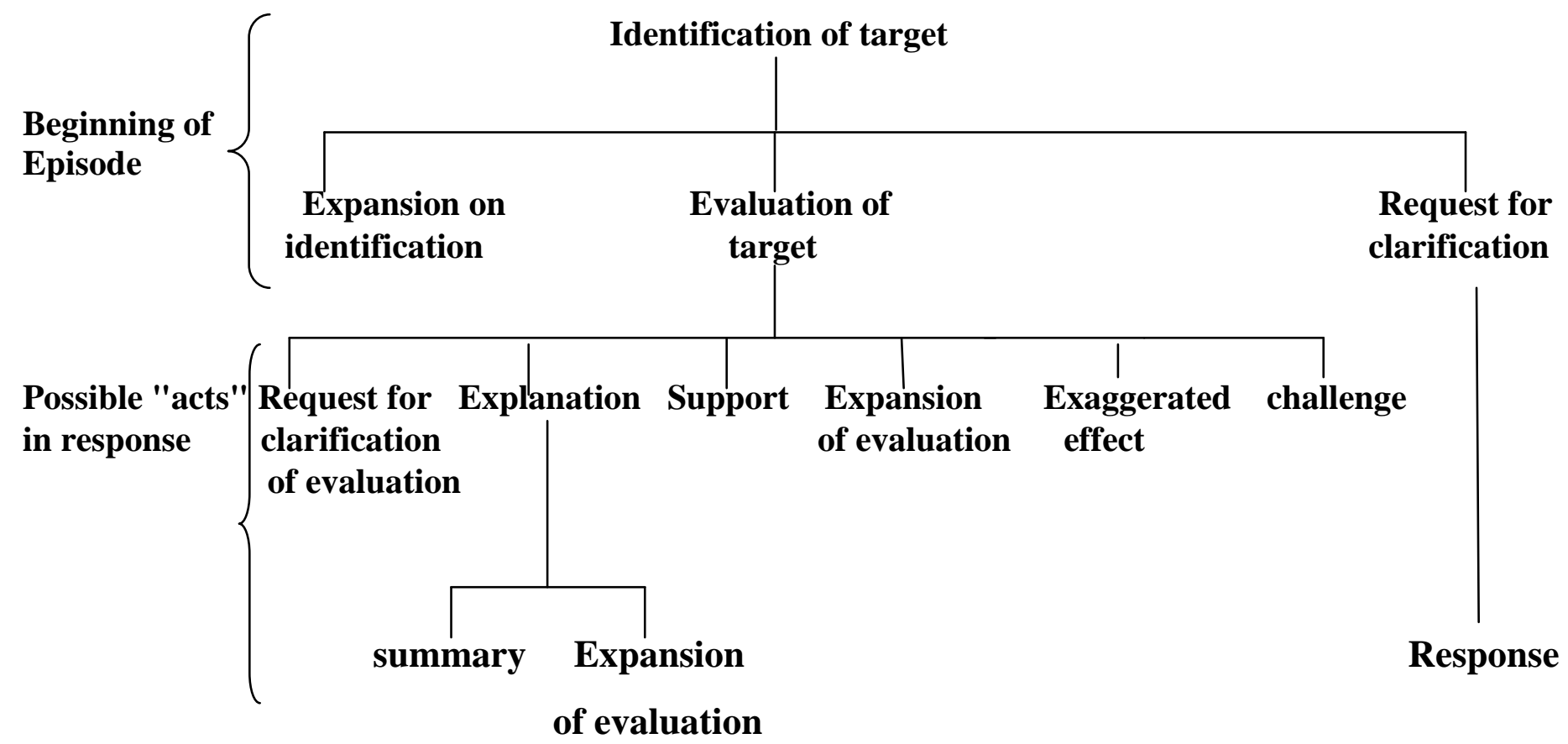

Figure (1): The Structure of a Gosisp Episode (Eder \& Enke, 1991: 499) 
In studying the structure of gossip, Eder and Enke (1991: 495) focus on "the ordering of acts within gossip episodes." As shown in figure (1), a gossip episode starts by the identification of a target followed by an expansion of identification, an evaluation of the target, and a request for clarification which can be followed by a response. The evaluation of the target is then followed by a number of "acts" including a request for clarification of the evaluation, an explanation, which can be followed by a summary or an expansion of evaluation, a support, an expansion of the evaluation, an exaggerated effect, or a challenge of the evaluation.

Eder and Enke (1991: 501) hold that any of these acts could occur at any point in the gossip episode except for challenges. They indicate that the reason for this is that "since the structure of gossip includes mainly acts that support the initial evaluation, it is much easier to continue to develop the expressed viewpoint of a group than it is to challenge it."

Analyzing the structure of adolescent gossip shows how adolescents recognize and take part in a gossip episode. Eder and Enke (1991: 500) show that when a target is identified and evaluated, group members realize that this is the beginning of a gossip episode. If 
they know the target, then they will start to take part in the gossip by providing explanations of the evaluation, expansions, and responses to clarification requests. Group members who are less familiar with the target ask for clarifications. They also indicate that "responses to evaluations are more important than the evaluations themselves in determining the nature of subsequent responses" (Eder \& Enke, 1991: 505). In other words, initial responses to remarks about the identified target determine the nature of the responses in the remainder of the episode as "a supportive response constrains the group to continue to make additional supportive statements" (Eder \& Enke, 1991: 495).

Hallett, Harger, and Eder (2005) study the strategies of adult gossip through which they-adultschange the structure of gossip proposed by Eder and Enke (1991), and examine the modes of interaction through which these strategies are accomplished. They identify two main strategies of adult gossip: indirectness and avoidance. The strategy of indirectness serves to protect gossipers because when this strategy is used, "the negative evaluations that characterize gossip remain implicit. If called to account, the gossipers could say 
'that's not what was said'." (Hallett, Harger, \& Eder, 2005: 8). Avoidance helps protect and negate power and status because by using this strategy, the negative evaluations made about the absent target can be preempted or redirected to others. Thus, avoidance helps protect the target from the negative aspects of gossip and assigns them to others (Hallett, Harger, \& Eder: 2005: 8).

Hallett, Harger, and Eder (2005:26) indicate that the strategy of indirectness is accomplished by four modes of interaction: implied evaluation via juxtaposition, sarcasm to implicitly evaluate, a request for clarification that indirectly expands the evaluation, and sarcasm to implicitly challenge. The avoidance strategy, on the other hand, is accomplished via six modes of interaction, namely preemptive positive evaluation, partial challenge, switch to another target, preemptive topic change, forcing directness, and withdrawal of challenge. The authors have shown that the content of gossip is closely related to its form because identifying and understanding how adults gossip, i.e. the form of adult gossip, helps understand the content of gossip. They also indicate that although 
the structure of adult gossip bears some resemblance to Eder and Enke's (1991) structure of gossip, adult gossip is more complex than adolescent gossip. This is because although adults identify and evaluate a target, support the evaluation, request clarification, and challenge, they use the strategies of indirectness and avoidance, thereby manipulate the basic structure of gossip because "while the indirect strategy keeps meaning implicit, the avoidance strategy shifts possible outcomes, placing the negative evaluations that are common to gossip elsewhere" (Hallett, Harger, \& Eder, 2005: 2).

To the best of the researcher's knowledge, no previous research has compared the structure and strategies of gossip in the speech of adolescents and adults nor studied this activity cross-culturally. Therefore, this paper fills two gaps in the literature: it compares two different age groups (adolescents as compared to adults) and examines the effect of age on the structure and strategies of gossip. 


\section{Results and Discussion}

In this section, the strategies and structure used by adolescent and adult Egyptians and native English speakers are presented and analyzed.

\subsection{Adolescent Egyptians and Native English Speakers}

\subsubsection{Strategies of Adolescent Gossip}

The data obtained in this study indicates that adolescent Egyptians and native English speakers employ a number of strategies when gossiping. Table (1) demonstrates these strategies as well as the frequency of their occurrence.

Table (1): The Frequency of Occurrence of Gossip Strategies in the Speech of Adolescent Egyptians and Native English Speakers

\begin{tabular}{|l|c|c|c|}
\hline \multicolumn{1}{|c|}{ Strategy } & Egyptians & $\begin{array}{c}\text { Native English } \\
\text { Speakers }\end{array}$ & Total \\
\hline $\begin{array}{l}\text { Partial } \\
\text { agreement }\end{array}$ & $4(44.5 \%)$ & $5(55.5 \%)$ & 9 \\
\hline Topic change & $4(50 \%)$ & $4(50 \%)$ & 8 \\
\hline $\begin{array}{l}\text { Challenging the } \\
\text { evaluation }\end{array}$ & $7(54 \%)$ & $6(46 \%)$ & 13 \\
\hline $\begin{array}{l}\text { Making } \\
\text { suggestions }\end{array}$ & $3(37.5 \%)$ & $5(62.5 \%)$ & 8 \\
\hline $\begin{array}{l}\text { Using sarcasm to } \\
\text { implicitly and } \\
\text { negatively } \\
\text { evaluate the } \\
\text { target }\end{array}$ & $6(60 \%)$ & $4(40 \%)$ & 10 \\
\hline
\end{tabular}


Table (1) shows that some strategies are used more by adolescent Egyptians while others are used more by adolescent native English speakers. Adolescent Egyptians tend to challenge each other's evaluation of the target in a gossip episode and evaluate him/her implicitly and negatively via sarcasm more than native English speakers. While challenging the evaluation occurs 7 times $(54 \%)$ in the gossip episodes of adolescent Egyptians, it occurs 6 times (46\%) in those of native English speakers. Using sarcasm to implicitly and negatively evaluate the target occurs 6 times $(60 \%)$ in the gossip episodes adolescent Egyptians and 4 times (40\%) in those of adolescent native English speakers in whose gossip episodes partial agreement and making suggestions occur 5 times each. In other words, these two strategies are used more by adolescent native English speakers than by adolescent Egyptians in whose gossip episodes partial agreement occurs 4 times $(44.5 \%)$ and making suggestions occurs 3 times $(37.5 \%)$. The strategy of topic change occurs 4 times in the gossip episodes of both adolescent Egyptians and native English speakers. Generally, the data reveals that adolescent Egyptians tend to challenge, rather than agree with, each other when gossiping. Therefore, the 
percentage of using the strategy of challenging is higher than that of partial agreement (54\% vs. $44.5 \%)$. The data also shows that sarcasm is common in the speech of adolescent Egyptians and this explains the high percentage of using sarcasm to implicitly and negatively evaluate the target in the gossip episodes of adolescent Egyptians $(60 \%$ compared to $40 \%$ in the gossip episodes of adolescent native English speakers). Because changing the topic to end the gossip episode is common practice, it occurs 4 times (50\%) in the gossip episodes of both adolescent Egyptians and native English speakers.

A close examination of the gossip episodes in the speech of adolescents, both Egyptians and native English speakers, reveals that they employ similar strategies when gossiping. It has also been noticed that when all group members are familiar with the target, certain gossip strategies are used but when not all of them are familiar with the target, other strategies are used. The similar strategies used when there is shared knowledge of the target of gossip are partial agreement, topic change, and a challenge of the evaluation. Although challenging the evaluation was an act in 
response to the initial evaluation in Eder and Enke's (1991) study, the data in the present study shows that it is a gossip strategy achieved by using four techniques. These are: defending the target, making a positive evaluation of the target, asking a question to elicit agreement to the counter viewpoint, and criticizing the other speaker.

Partial agreement, as shown in extracts (1) and (2) below, is indicated by the use of words like "True" and "No", and phrases like "That's correct" and "you're right". These words and phrases are then followed by the conjunction "but" which shows that there is some disagreement with the other speaker's proposition, and this is evidenced in making negative evaluations after "but".

\section{Extract (1):}

1- Tom: What you're saying isn't true. Sally is right; she said these parts weren't important but she explained everything else.

2- Kara: And she did a couple of exercises on the parts she explained.

3- Maria: True but most of our answers in class were incorrect. Doesn't that tell you something? 
In extract (1), three native English speaking students are talking about their Arabic teacher. Maria believes that the teacher did not cover the lesson well. In line 1, Tom challenges Maria's proposition and defends the teacher. In line 2, Kara expands on Tom's explanation and Maria partially agrees with Kara in line 3 by saying "True" then she immediately criticizes her-Kara's- comment saying "but most of our answers in class were incorrect."

\section{Extract (2)}

1- Basma: howwa kaan bijzaৎa? lelli kaanu kol Jowajja bijeৎmelu hârâkât uâlâț wi Gandu ha? la?in kol hârâkâ fi Pelsebaaha laazim teb?a ṣâh

"He was yelling at those who made wrong movements, and he's right because every movement in swimming must be correct."

2- Esraa: kallamik maẓbuut bas mif keda da kaan mezawedha Pawi Pana mif fahma howwa leeh faajef nafsu keda safaat 
"That's correct but not in this way. He overdid it and I don't understand why he's so full of himself sometimes."

3- Basma: boṣ̣i howwa șâhiih safaat bijetkalim ketiir bas biṣârâhâ lamma bineYmil Pelhârâkât kollaha șâh bijfagafna walla tenkeri ?enu bijeSmil keda

"Look, it's true that sometimes he talks a lot but honestly, he encourages us when we do the movements correctly. Do you deny that?"

4- Esraa: la? bas bârdu dammu te?iil Sala Palbi wi kamaan mi $\min$ ha?u Penu jellaba $\chi$ fiina walla Pana sâlțâna

"No but still I don't like him, and also he has no right to scold us or am I mistaken?"

5- Basma: maSaaki ha? bas howwa mi $\int$ bijjefmel keda Yâlâ țuul "You're right but he doesn't do this all the time." 
In this extract, two Egyptian friends, Esraa and Basma, are talking about their trainer. In line 1, Basma defends the target and justifies his yelling at girls in the swimming practice. In line 2, Esraa agrees with Basma but this is only partial agreement because she immediately makes a negative evaluation saying that he is "full of himself". Basma partially agrees with Esraa in line 3 by making a negative evaluation of the trainer that supports her-Esraa's-evaluation of him in line 2 and then makes a positive evaluation. After making this positive evaluation, Basma asks a question in line 3 to make Esraa agree with her and the latter agrees. However, her agreement is only partial as she then makes another negative evaluation of the target saying, "he has no right to scold us" and asks "am I mistaken?" Although Basma agrees in line 5, again this is just partial agreement because she defends the trainer saying "but he doesn't do this all the time."

Topic change is used to end the gossip episode when there is no convergence in the speakers' opinions and the conversations are structured around challenges and counter challenges. This strategy is shown in extracts (3) and (4): 
Extract (3)

1- Maria: True but most of our answers in class were incorrect. Doesn't that tell you something?

2- Tom: But she explained why our answers were incorrect and said the correct ones.

3- Maria: Anyway let's just forget the homework and all this stuff. What's the plan for the weekend?

In extract (3), Maria tries to criticize the target-the Arabic teacher- in line 1 but Tom jumps in to provide a positive evaluation of the teacher thereby challenge Maria's proposition. Then Maria changes the topic in line 3 by asking about the plan for the weekend to avoid making further negative evaluations about the teacher as she knows that her colleagues will challenge her comments.

\section{Extract (4)}

1- Omar: țâbৎân misaali wi Yaadel laa?enu mif min PelSadl Penu jesaawi been Pelli Peftasal we Pelli maftaralf 
"Of course he's ideal and fair because it's not fair to treat those who worked hard and those who didn't work equally."

2- Mustafa: $\chi$ alluna nefuuf haneSmil Peeh fi Pilbahas

"Let's see what we'll do in the research paper."

3- Aya: Sandaak ha? jalla nebda? ?elforl

"You're right. Let's get to work."

In this extract, a group of Egyptian university students are in the Bibliotheca Alexandrina working on a research paper, and they are dissatisfied with the topic on which they are supposed to do a research paper. Omar defends the target-Dr. Emad who is their professor - against his colleagues' criticism of him. In line 2, Mustafa changes the topic and tells his friends to start thinking of what they will do in the research paper and Aya supports him in the next line. Thus, Mustafa and Aya attempt to end the gossip episode. 
As mentioned earlier, group members use four techniques to challenge each other's propositions, namely defending the target, making positive evaluations of him/her, asking a question to elicit agreement, and criticizing the other speaker. These techniques are not used by any speaker who wants to challenge the other speaker. In other words, they are not used by all the participants in the gossip episodes. Rather, they are used by the speakers who disagree with the initial evaluation made about the target at the beginning of the gossip episode. Then, when the speakers who make the initial evaluation wish to disagree with those who challenge their evaluations, they challenge them by making negative evaluations of the target. The first two techniques, namely defending the target and making positive evaluations of him/her are shown in extracts (5) and (6).

\section{Extract (5)}

1- Tom: Can't say I did it really well. I don't think any of us got the whole lecture but maybe [

2- Maria: [may be the teacher didn't cover the lesson well. 
3- Kara: No, I can't blame her. She did a good job. You're not being fair, Maria. Remember, you couldn't concentrate well the other day coz you weren't feeling well.

4- Maria: but she skipped some parts and I don't remember she made it clear why she did so.

5- Tom: What you're saying isn't true. Sally is right; she said these parts weren't important but she explained everything else.

6- Kara: And she did a couple of exercises on the parts she explained.

7- Maria: True but most of our answers in class were incorrect. Doesn't that tell you something?

8- Tom: But she explained why our answers were incorrect and said the correct ones.

In extract (5), Maria identifies the Arabic teacher as the target of gossip in line 2 and evaluates her negatively. However, in line 3, Kara makes a positive evaluation of the teacher and defends her saying "I can't blame her. She did a good job." When Maria disagrees with Kara in line 4 and provides another negative evaluation of the teacher, Tom challenges her 
proposition in line 5 and defends the teacher. So he provides support for Kara's initial challenge in line 3, saying "she said these parts weren't important but she explained everything else." In line 6, Kara agrees with Tom and expands on his positive evaluation of the teacher. When Maria challenges Kara in line 7, Tom makes another positive evaluation in line 8 to defend the target.

\section{Extract (6)}

1- Mona: wi howwa keda jeb?a misaali me keda

"And this makes him ideal, yes?"

2- Omar: țâbৎân misaali wi Gaadel laa?enu mið min PelGadl Penu jesaawi been Pelli Peftasal we Pelli majtaralf

"Of course he's ideal and fair because it's not fair to treat those who worked hard and those who didn't work equally."

In this extract, Mona's comment in line 1 has a sarcastic tone that serves as another implied negative evaluation of the target but Omar confirms the positive 
quality of the target and makes another positive evaluation by describing the doctor as "fair" and expands on his positive evaluation in an attempt to confirm his viewpoint of the target.

The third challenging technique, namely asking a question to elicit agreement, is used by adolescent Egyptians only and is not found in the speech of adolescent native English speakers. This technique is illustrated in extracts (7) and (8).

\section{Extract (7)}

1- Mustafa: baajen Galeeh fakerna Pahmad zoweel fi zamaanu

"It seems he thinks we're Ahmed Zoweil."

2- Omar: mafiif mojkela ?en Pehna neftaral wi neţab Pahmad zoweel mawâsâll lelli howwa fi bishuula walla ?eeh?

"It's ok that we work really hard. Did Ahmed Zoweil reach such a high rank easily?" 
In this extract, Mustafa makes fun of the target as the latter wants them to work hard so he comments by saying, "It seems he thinks we're Ahmed Zoweil" but Omar defends the target and asks Mustafa "Did Ahmed Zoweil didn't reach such a high rank easily?" to elicit agreement to the truth of what he is saying.

\section{Extract (8)}

1- Ahmed: bijohfor nafsu fi kol haaga texoșṣeni

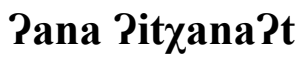

"He interferes in everything that concerns me. I've had it."

2- Karim: Pakiid howwa faajez mâșlâhtak faadi zajjo zaj Paj Pâb Paw Pom ma Gajziin mâṣ̂âhet weladhom walla Pana batkallem Paj kalaam "He surely wants what's good for you just like all parents who want what's good for their kids. Am I talking nonsense?"

In extract (8), Ahmed and Karim, two Egyptian friends, are talking about the former's father. Ahmed complains that his father always interferes in 
everything in his life. Because Karim does not have sufficient knowledge that would enable him to support or challenge Ahmed's proposition, he replies in line 2 by making a general comment saying that parents want what is best for their children. Then he asks the question "Am I talking nonsense?" to force Ahmed to agree to his proposition.

Criticizing the other speaker, which is the last challenging technique, is shown in extracts (9) and (10).

\section{Extract (9)}

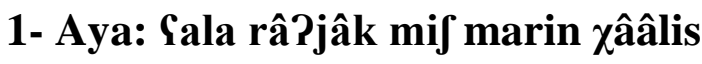

"You're right; he's not lenient at all."

2- Mustafa: wi ?iidu naffa Pawii fi Peldârâgâât

"And he's not generous when it comes to marks."

3- Omar: Pentu biteddalafu Pilmas?ala mif mas?alet Penu mif marin Paw Peedu naffa fi Peldârâgâât Peldoktor da ha??aani la?enu bijeddi 
kol țââlib ha?u Pelli jestaha?u bilzâbṭ wi Gala Pad ma Peftaral

"You're spoiled. It's not a matter of not being lenient or ungenerous with marks. The doctor is fair and gives every student his/her due depending on how much he/she worked."

In extract (9), Aya and Mustafa make negative evaluations of the target by describing him as "not lenient" and "not generous when it comes to marks" but Omar criticizes his colleagues saying, "you're spoiled," and makes another positive evaluation of the target that serves to defend him.

\section{Extract (10)}

1- Tom: Can't say I did it really well. I don't think any of us got the whole lecture but maybe [

2- Maria: [may be the teacher didn't cover the lesson well. 3- Kara: No, I can't blame her. She did a good job. You're not being fair, Maria. Remember, you couldn't concentrate well the other day coz you weren't feeling well. 
In extract (10), the gossip episode starts in line 2 when Maria identifies the Arabic teacher as the target of gossip and makes a negative evaluation of her. However, Maria's negative evaluation is challenged by Kara in line 3 who explicitly disagrees with Maria and defends the teacher saying, "I can't blame her. She did a good job," and criticizes her colleague by accusing her of not being fair because she did not concentrate well in class as she was not feeling well.

The above-mentioned strategies, namely partial agreement, topic change, and challenging, are found in conversations in which there is shared knowledge of the target among the group members. However, one gossip strategy which is common between adolescent Egyptians and native English speakers and which is used when not all group members are familiar with the target is making suggestions. This strategy is illustrated in extracts (11) and (12). 
Extract (11)

1- Laura: Why don't you ask him what's wrong?

2- Clara: No good. It won't work. Things are just so messed up between us. We don't seem to click anymore.

In extract (11), Clara and Laura, two native English speaking friends, are discussing the former's relationship with her boyfriend, Tim. Laura here makes a suggestion in an attempt to help Clara find a solution to the problem she has with her boyfriend, and the latter evaluates the suggestion saying "No good. It won't work" and explains the reason for her evaluation.

\section{Extract (12)}

1- Karim: tâjjeb haawel tetkalem mạaa taani wi teqnefu bi ra?jak wi Pesmå weghet nâzâru jemken waahed menkom je?dar jeqnef Peltaani bi weghet nâzâru Paw tewṣâlu lehal wâsâț "Ok, try to talk to him again and convince him of your opinion, and listen to his viewpoint. May be one of you will be able to convince the other of his viewpoint or you might reach a compromise." 
2- Ahmed: mif hajgiib nattiga la?enu Senadi wi moṣâmim jexalliini Pa Padim wara?i fi Peltegârâ

"This will be useless because he is stubborn and insists on making me present my papers in the faculty of commerce."

In extract (12), Karim suggests that Ahmed talks to his father to try to solve the problem but Ahmed rejects the suggestion by making another negative evaluation of his father by describing him as "stubborn".

Only the initiators of the gossip episode in extracts (11) and (12) are familiar with the target. The other group members in these extracts seem to have insufficient background knowledge about the target and so they make suggestions in an attempt to help the other speakers-the initiators of the gossip episode-by offering possible solutions to their problems.

One strategy that is common between adolescent Egyptians and native English speakers, whether there is shared, or lack of, background knowledge about the target, is the use sarcasm to implicitly and negatively 
evaluate the target. This strategy is found in extract (13) from conversation (2) (see Appendix B), in which all group members are familiar with the target, and extract (14) from conversation (5) (see Appendix B), in which Jane does not have enough background knowledge about the target. In the two extracts, speakers employ this strategy by using positive adjectives which imply that the opposite is what is meant.

\section{Extract (13)}

1-Omar: Pentu biteddalaYu Pilmas?ala mif mas?alet Penu mif marin Paw Peedu naffa fi Peldârâgâât Peldoktor da haP?aani laPenu bijeddi kol țââlib ha?u Pelli jestaha?u bilzâbṭ wi Sala Pad ma Peftasal

"You're spoiled. It's not a matter of not being lenient or ungenerous with marks. The doctor is fair and gives every student his/her due depending on how much he/she worked."

2-Mona: wi howwa keda jeb?a misaali me keda

"And this makes him ideal, yes?" 
In this extract, when Omar makes a positive evaluation of the target in line 1 , Mona makes a sarcastic comment in the form of a positive evaluation of the target by using the positive adjective "ideal".

\section{Extract (14)}

1- Sara: Glad it's break time.

2- Jane: Yeah

3-Sara: But what I need is not a break between classes. I need a break from Julia, my special roommate, my beloved roommate.

In this extract, two native English speaking students, Sara and Jane, are talking about Julia, Sara's roommate. Sara says that what she needs is not a break from classes but a break from her roommate who she sarcastically describes using two positive adjectives: "special" and "beloved".

The above analysis demonstrates that adolescent Egyptians and native English speakers employ similar, rather than different, strategies when gossiping. The use of these similar strategies depends on the presence or 
absence of shared knowledge of the target of gossip among participants in the gossip episode.

\subsubsection{Structure of Adolescent Gossip}

The structure of gossip in the speech of adolescent Egyptians and native English speakers is generally similar to the structure of adolescents' speech proposed by Eder and Enke (1991). Extracts (15) and (16) demonstrate the structure of adolescents' gossip in the present study.

\section{Extract (15)}

1- Mona: doktor șâfb Pawi Peeh Pelmawḍuu

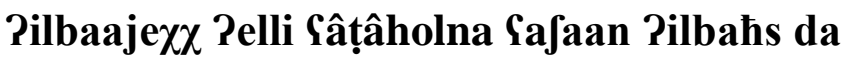
"Dr. Emad is so difficult. What's this uninteresting topic that he gave us for the research paper?"

2- Aya: Pajwa wi mif keda wi bas da kamaan

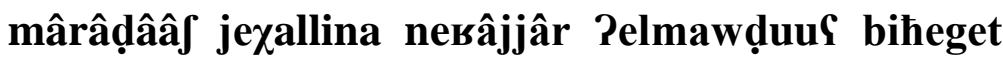
Penu ؟ajzna nebzil maghuud wi nestaৎmil mârâgeৎ moxtalifa 
"Yes and not only this. He also refused to make us change the topic under the pretext that he wants us to exert an effort and use different references."

In this extract, Mona identifies Dr. Emad, a university teacher, as the target of gossip and makes a negative evaluation of him by describing him as a difficult person. In line 2, Aya supports Mona's evaluation of the target and expands on her evaluation. In other words, the identification of the target in this extract is followed by an evaluation which in turn is followed by support and expansion on evaluation.

\section{Extract (16)}

1- Emma: But what I need is not a break between classes. I need a break from Julia, my special roommate, my beloved roommate.

2- Jane: What do you mean?

3- Emma: I've had it with her. She's such a pain in the neck, a really messy person.

4- Jane: Come on, tell me about it.

5- Emma: She always leaves the place in a mess; the kitchen, the bathroom, the living room and the 
bedroom are all so untidy and messy. And whenever I tell her that we need to divide the labor and clean our flat at least once a week, she just says "we'll see". She's a real snob.

In extract (16), when Emma identifies Julia as the target of gossip and sarcastically evaluates her by describing her as "special" and "beloved", Jane requests a clarification which indicates that she is not familiar with the target. Then Emma replies in line 3 by providing an explanation, and in line 5 , she expands on her evaluation of the target. In other words, the identification of the target is followed by an evaluation and a request for clarification of the evaluation. This in turn is followed by an explanation then an expansion of the evaluation.

One difference between adolescent Egyptians and adolescent native English speakers concerning the structure of gossip has been found. This difference is concerned with one of the acts of response given in Eder and Enke's 1991 study, namely the act of challenging. In the speech of adolescent Egyptians, speakers do not necessarily challenge the initial evaluation immediately after it is made. Rather, in Egyptian adolescents' 
speech, the initial evaluation could be supported by a group member first before it is challenged by another speaker. This is contrary to the findings of Eder and Enke (1991: 502) who hold that "once a response from another group member supported the initial evaluation, other group members made only supportive comments" (1991: 502). Challenging in the speech of adolescent Egyptians is demonstrated in extract (17).

\section{Extract (17)}

1- Mona: doktor Pelmadda di șậb Pawi Peeh Pelmawḍuu Pilbaaje $\chi$ Pelli Sâțâholna Safaan Pilbahs da

"The doctor of this course is so difficult. What's this uninteresting topic that he gave us for the research paper?"

2- Aya: Pajwa wi mi keda wi bas da kamaan

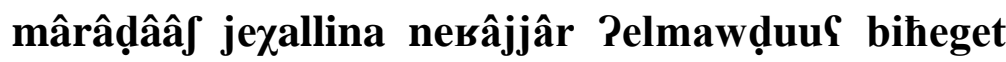
Penu Sajzna nebzil maghuud wi nestaৎmil mârâgeS moxtalifa 
"Yes and not only this. He also refused to make us change the topic under the pretext that he wants us to exert an effort and use different references."

3- Mustafa: baajen Galeeh fakerna Pahmad zoweel fi zamaanu

"It seems he thinks we're Ahmed Zoweil."

4- Omar: mafiif mojkela ?en ?ehna neftaral wi neţab Pahmad zoweel mawâsâll lelli howwa fi bishuula walla ?eeh?

"It's ok that we work really hard? Did Ahmed Zoweil didn't reach such a high rank easily?"

In extract (17), Mona makes a negative evaluation of the target in line 1 and is supported by Aya in line 2 and by Mustafa in line 3 but is challenged by Omar in line 4. Although three out of four speakers in this extract make consecutive negative evaluations of the target in the first three turns of the episode (see conversation (2) in Appendix B), a challenge still occurred. In other words, support for the initial 
negative evaluation does not prevent the occurrence of a challenge.

Adolescent native English speakers, on the other hand, tend to challenge the initial evaluation of the target right after it is made. Thus, similar to Eder and Enke's study, "challenges...occurred only in the speaking turn immediately following the initial evaluation" and when the initial challenge is made, "most of the participation by other members is in the form of supportive remarks" (Eder \& Enke, 1991: 502). This is illustrated in extract (18).

\section{Extract (18)}

1- Maria: [may be the teacher didn't cover the lesson well.

2- Kara: No, I can't blame her. She did a good job. You're not being fair, Maria. Remember, you couldn't concentrate well the other day coz you weren't feeling well.

Maria here makes a negative evaluation of the Arabic teacher in line 1 and she is immediately challenged by Kara in the next line. Kara's initial 
challenge is further supported by Tom in the rest of the episode (see conversation (4) in Appendix B).

\subsection{Adult Egyptians and Native English Speakers}

\subsubsection{Strategies of Adult Gossip}

The analysed data shows that some strategies are used by adults, whether Egyptians or native English speakers, when gossiping. The frequency of occurrence of these strategies is shown in table (2). 
Table (2): The Frequency of Occurrence og Gossip Strategies in the Speech of Adult Egyptians and Native English Speakers

\begin{tabular}{|c|c|c|c|}
\hline Strategy & Egyptians & $\begin{array}{c}\text { Native English } \\
\text { Speakers }\end{array}$ & Total \\
\hline $\begin{array}{l}\text { Speakers finish each } \\
\text { other's utterances }\end{array}$ & $4(57 \%)$ & $3(43 \%)$ & 7 \\
\hline $\begin{array}{l}\text { Using explicit } \\
\text { indicants of } \\
\text { agreement }\end{array}$ & $3(37.5 \%)$ & $5(62.5 \%)$ & 8 \\
\hline $\begin{array}{l}\text { Using exclamatory } \\
\text { questions }\end{array}$ & $4(50 \%)$ & $4(50 \%)$ & 8 \\
\hline $\begin{array}{l}\text { Using facilitative } \\
\text { questions }\end{array}$ & $5(50 \%)$ & $5(50 \%)$ & 10 \\
\hline $\begin{array}{l}\text { Making positive } \\
\text { evaluations about } \\
\text { the target }\end{array}$ & $5(55.5 \%)$ & $4(44.5 \%)$ & 9 \\
\hline $\begin{array}{l}\text { Justifying the } \\
\text { target's attitude }\end{array}$ & $3(37.5 \%)$ & $5(62.5 \%)$ & 8 \\
\hline $\begin{array}{l}\text { Making negative } \\
\text { evaluations about } \\
\text { the target }\end{array}$ & $6(50 \%)$ & $6(50 \%)$ & 12 \\
\hline $\begin{array}{l}\text { Criticizing the } \\
\text { target }\end{array}$ & $6(54.5 \%)$ & $5(45.5 \%)$ & 11 \\
\hline $\begin{array}{l}\text { Using explicit } \\
\text { indicants of } \\
\text { disagreemnet }\end{array}$ & $4(50 \%)$ & $4(50 \%)$ & 8 \\
\hline $\begin{array}{l}\text { Criticizing the other } \\
\text { speaker }\end{array}$ & $4(44.5 \%)$ & $5(55.5 \%)$ & 9 \\
\hline $\begin{array}{l}\text { Making religious } \\
\text { comments }\end{array}$ & $5(100 \%)$ & --- & 5 \\
\hline
\end{tabular}


Table (2) shows that while adult Egyptians finish each other's utterances 4 times (57\%), make positive evaluations about the target 5 times (55.5\%), and criticize the target 6 times (54.5\%), adult native English speakers finish each other's utterances 3 times (43\%), make positive evaluations about the target 4 times (44.5\%), and criticize the target 5 times (45.5\%). Religious comments are also made by adult Egyptians but not by adult native English speakers. The latter use explicit indicants of agreement 5 times (62.5\%) and criticize the other speaker 5 times $(55.5 \%)$ whereas adult Egyptians explicit indicants of agreement 3 times (37.5\%) and criticize the other speaker 4 times $(44.5 \%)$. Both adult Egyptians and native English speakers use exclamatory questions 4 times, facilitative questions 5 times, make negative evaluations about the target 6 times, and use explicit indicants of disagreement 4 times. The data reveals that the information provided by the initiator of the gossip episodes concerning the target determines the reaction of adult speakers towards what is said and the strategies used. This explains the differences and similarities in the percentages of occurrence of the above-mentioned strategies. 
Adults' speech in the present study is different from adolescents' speech in that adult speakers in most of the encounters in the analyzed data tend to agree with each other. The high degree of involvement found in the speech of adult speakers is reflected in the cooperative gossip strategies used to indicate this involvement. The involvement strategies illustrated below are common between Egyptians and native English speakers. The first of these strategies is the speakers' tendency to show involvement by finishing each other's utterances, as indicated in extracts (19) and (20).

\section{Extract (19)}

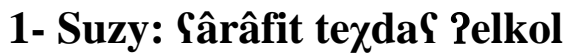

"She knew how to deceive everybody."

2- Amira: șâhiih kaanit tebaan țâjeba bas țâlâfit

"True. She seemed to be kind but turned out to

be [" 
3- Suzy: bas țâlâSit fâșejja bafißa rabena jekfiiki fârrâha wi fâ Pamsalha

"but turned out to be a horrible person. May God protect you from her wickedness and the wickedness of her likes."

In extract (19), two Egyptian friends, Amira and Suzy, are in the club and Suzy is complaining to Amira of her mother-in-law. When Suzy says, in line 1, that her mother-in-law deceived everybody, Amira replies in the next line by saying "True. She seemed to be good but turned out to be..." Before, she-Amira-finishes her utterance, Suzy butts in and finishes her utterance by repeating the phrase "but turned out to be" then making a negative evaluation of the target by describing her as "a horrible person."

\section{Extract (20)}

1-Margaret: Gosh! Things just got worse. They quarreled all the time and he started to beat her and took her money and being his mother's [

2- Lesley:

[spoiled

brat 


\section{3- Margaret: Exactly}

In extract (20), Lesley and Margret, two native English speaking friends, are talking about Dorothy, Margaret's daughter and her husband from whom she got a divorce. Lesley wants to know how things were like after Dorothy's ex-husband left his job, so Margaret says, "Gosh! Things just got worse, you know. They quarreled all the time and he started to beat her and took her money, and being his mother's..." and Lesley immediately finishes Margaret's sentence in the next line by saying, "spoiled brat".

In finishing each other's utterances in extracts (19) and (20), the interrupters in both examples make negative evaluations about the target. However, in extract (19), unlike extract (20), it is Suzy, who is involved in the problem, rather than Amira, who is an outsider, who interrupts to make a negative evaluation about the target. Most probably, before she is interrupted, Amira was also going to make a negative evaluation about the target based on what Suzy tells her about her mother-in-law throughout the encounter. In extract (20), on the other hand, Lesley, the outsider who is not involved in the problem, interrupts Margaret, 
who is involved in the problem, and makes a negative evaluation of Dorothy's ex-husband. Therefore, it seems that Lesley has some background knowledge about Dorothy's ex-husband because when she makes this negative evaluation, Margaret confirms this description in line 3 by saying, "Exactly".

Another involvement strategy that is used is showing agreement via explicit indicants of agreement. These include lexical items like "yes", "yeah", and "true", and phrases like "you're right" and "of course". This strategy is shown in extracts (21) and (22):

Extract (21)

1- Margaret: Yeah, she's been though too much at such an early age. Poor thing!

2- Lesley: Well, she's the one to blame. What could a woman like in a man like Steve? I just don't get it. He was a real misfit.

3- Margaret: True. Personally, I always thought so and never actually liked him. 
In extract (21), Lesley and Margaret start their conversation by talking about Dorothy. When in line 1, Margaret pities her daughter because "she's been through too much at such an early age," Lesley, in line 2, blames Dorothy for making a wrong choice and makes a negative evaluation about Steve-her ex-husband-by describing him as "a real misfit." Because she knows that Lesley is right, Margaret explicitly agrees with her in the next line by saying "True" and confirms this agreement by telling Lesley how she felt about her daughter's ex-husband.

Extract (22)

1- Kate: He changed his seemingly nice way of treating tourists and pulled a face and murmured and pouted.

2- Freddie: That's rude.

3- Kate: So you're starting to agree

4- Freddie: of course.

In extract (22), two tourists, Freddie and Kate, are talking about a shop seller in Khan El-Khalili. Throughout this conversation, Freddie and Kate do not 
see eye to eye as the latter is of the opinion that the seller is greedy and is not a nice person but the former has a different take. When, in line 1, Kate says that the seller "changed his seemingly genuine nice way of treating tourists and pulled a face and murmured and pouted" when she and Freddie left without buying anything, Freddie expresses his resentment at the seller's attitude saying, "That's rude." Because this is the first time that Freddie agrees with Kate, the latter says to him in line 3, "So you're starting to agree" and he confirms by using the explicit indicant of agreement "of course" in line 4.

Another involvement strategy found in the speech of adult Egyptians and native English speakers is the use of exclamatory questions to show surprise. This strategy is found in extracts (23) and (24). It is noticeable that the exclamatory questions are followed by either general comments or negative evaluations about the target.

Extract (23)

1-Dr. Ayman: ma Pana lamma Poltelu Pin Peltawzii؟ Petsâjjâr laPetu bijPuul lelțâlâbâ 59 
bituufu PoPafu Poddaam maktab wikiil Pelkolleja lefo?uun Pelṭollââb wi Pef̣̣âlu wa?fiin hinaak lehad ma jehel Pelmofkela wi law Peljoom Pentaha min seer Pelmofkela tethal hanaxod Pelmohâḍ̂â PelPosbuu Yelgaj filțor?a Pelli Poddam Pilqâfâ betaSetna

"When I told him that the distribution has changed, he told his students to go and stand in front of the office of the vice dean for students' affairs and to remain standing there till the problem is solved, and if, by the end of the day, the problem is not solved, they'll take the lecture in the corridor in front of the hall."

2- Dr. Yehia: Peeh da tâhriị̣ șâriih da Pakiid

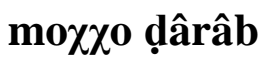

"What? This is clear instigation. He must have lost his mind."

In extract (23), Dr. Ayman, a faculty member, is telling his friend and colleague, Dr. Yehia, about a problem that happened between him, Dr. Ayman, and another colleague, Dr. Mohamed, concerning a lecture hall. Dr. Ayman tells Dr. Yehia that the target of gossip, Dr. Mohamed, tried to use his-Dr. Ayman's-lecture hall 
thinking that it is his. When, in line 1, Dr. Ayman says that when he told Dr. Mohamed that the distribution of halls among the departments in the faculty has changed, he was not convinced and asked his students to stand in front of the office of the vice dean till the problem is solved, and if it is not solved then they will take the lecture the following week in the corridor in front of the lecture hall. In line 2, Dr. Yehia expresses his extreme surprise saying, "What?" and comments on this behavior saying, "That's clear instigation" to express his resentment with Dr. Mohamed's behavior. Then, he makes a negative evaluation of Dr. Mohamed saying that he "must have lost his mind."

\section{Extract (24)}

1- Barbara: But before we came here, his teacher told me he started to be aggressive and rude with the other kids in school.

2- Jackie: What? That's bad and it's very unlike him. He's becoming a troublemaker.

In extract (24), two foreign friends, Jackie and Barbara, are talking about Mark, Barbara's son. 
Barbara is telling Jackie that she is worried about Mark whose father's death is affecting him badly. In line 1, Barbara tells Jackie that Mark "started to be aggressive and rude with the other kids in school" and Jackie shows her surprise in line 2 by using the exclamatory question "What?" She also comments on Mark's behavior describing it as "bad" and "very unlike him" and negatively evaluates Mark himself saying, "He's becoming a troublemaker."

Adult speakers also show their involvement in each other's talk by using another kind of questions, namely "facilitative" questions that encourage the hearer "to respond more fully...and led to extended responses" (Holmes, 1995: 48). In other words, facilitative questions invite the hearer to give detailed answers to the question being asked. This involvement strategy is seen in extracts (25) and (26).

\section{Extract (25)}

1- Margaret: True. Personally, I always thought so and never actually liked him. 
2- Lesley: But you never said anything. Don't you think that's strange?

3- Margaret: No, I couldn't have said anything coz she loved him, but I always noticed he was so arrogant and showy and untrustworthy.

In extract (25), a facilitative question occurs in line 2 in which Lesley says, "But you never said anything. Don't you think that's strange?" in response to Margaret's reply in line 1 when she says that she never liked Dorothy's ex-husband. Lesley's question implies that Margaret never showed or said that she didn't like her daughter's ex-husband. Because Lesley is surprised, she wants Margaret to explain the reason for her attitude, and this is what she does in line 3 .

\section{Extract (26)}

1- Dr. Yehia: wi Samalt Peeh

"And what did you do?"

2- Dr. Ayman: Poltelu Pin Pelqâfâ betaSti binaa?an Sala tawziị Pelqâৎâât Pelli Pettafa?at Saleeh kol PelPâqsaam fi PelPigtemaS Pelli Samalu wikiil Pelkolleja lefo?uun Pelțollâb wi Pin qesmu howwa 
Pelqesm Pelwahiid Pelli mahâṭ̂rf momasiliin Sannu

"I told him that the hall is mine according to the distribution that was decided upon by all the departments in the meeting held by the vice dean for students' affairs. I also told him that his department was the only one from which there were no representatives in the meeting."

3- Dr. Yehia: țâbৎân Pelkalaam da majeৎgaebhuuf "Of course, he wouldn't like this talk."

4- Dr. Ayman: țâbৎân la?

"Of course not."

5- Dr. Yehia: wi kaan Peeh râd feYlu

"And what was his reaction?"

6- Dr. Ayman: Palli Penu maafi Gala Peltawzii Pelli mâḍâ Yaleeh PelSamiid Pabl keda 
"He told me that he is following the distribution that the dean signed before."

Facilitative questions occur twice in extract (26). In line 1, Dr. Yehia asks, "And what did you do?" as he wants to know Dr. Ayman's reaction when Dr. Mohamed interrupted him while teaching and told him that he has taken his lecture hall. Dr. Ayman replies in line 2 by giving an extended response. Because both speakers know that Dr. Mohamed would not like Dr. Ayman's response in line 2, Dr. Yehia asks another facilitative question in line 5 about the target's reaction to Dr. Ayman's response and the latter answers extensively in line 6.

In addition to the above mentioned involvement strategies, some disagreement strategies have been found in the speech of adult speakers. These disagreement strategies are either pro-target or antitarget, i.e. a speaker can disagree with another by using strategies that show that the speaker is on the target's side or strategies which indicate that the speaker is against the target. Pro-target disagreement strategies involve making positive evaluations about the target 
and justifying the target's attitude. The first strategy is found in extracts (27) and (28).

\section{Extract (27)}

1- Kate: Because he was so hard-headed and wouldn't cut down the price of anything we wanted to buy.

2- Freddie: But he was welcoming.

When Kate negatively evaluates the target by describing him as "hard-headed" in line 1, Freddie challenges her by making a positive evaluation of the seller in line 2 by saying he was "welcoming".

\section{Extract (28)}

1-Ashraf: howwa laazim jegiib Peldârâgâ Pelneha?ejja Galafaan mostawaa majeb?aa\} ḍ̂âiif wi biṣârâhâ Pelmodarres da Pisterlaali

"Must he get the full mark so as not to be considered weak? And frankly, this teacher is a profiteer." 
2- Samar: bas howwa fââter wi faajez jehasin mostawa Pahmad mif la?enu bijhebu wa Penama laPinu hâriị̣ Pin țâlâbtu jegiibu dârâgâât Salja fi PelPemtahaan Safaan jehââfiz Sala som Yetu kamodarres qoṣuuṣi

"But he's clever and wants to improve Ahmed's level not because he likes him but because he's keen on making his students get high marks in the final exam as he wants to keep his reputation as a private teacher."

In extract (28), a husband, Ashraf, and his wife, Samar, are talking about Mr. Mahmoud, the Arabic teacher. Samar tells her husband that he-Mr. Mahmoud-wants to give extra private lessons to their son's group but Ashraf does not like the idea. In line 1, when Ashraf tells Samar that Ahmed, their son, does not have to get the full mark in order not to be considered weak and that the teacher is a profiteer, she makes a positive evaluation of the teacher in line 2 by describing him as "clever".

The second pro-target disagreement strategy, namely justifying the target's attitude, is found in extracts (29) and (30). In these extracts, the speakers 
who are on the target's side challenge the other speakers and seek to defend the target by justifying his attitude.

\section{Extract (29)}

1- Freddie: But he was welcoming.

2- Kate: No, he wasn't genuine. He's a clever actor.

3- Freddie: He's a clever guy and was simply trying to sell us some souvenirs.

In this extract, when Freddie tells Kate in line 1 that the seller "was welcoming", the latter disagrees with him saying that the seller "wasn't genuine" and that "he's a clever actor". But Freddie disagrees with Kate in line 3 by defending the seller and justifying his attitude by saying that he "was simply trying to sell some souvenirs".

\section{Extract (30)}

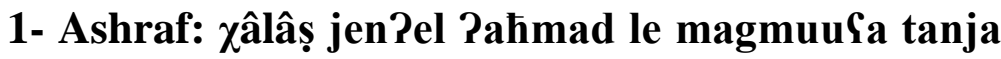
mostawaaha Pahsan min Pelmagmuufa Pelli howwa fiiha 
"Then tell him to move Ahmed to another group that's better than the one he's in now."

2- Samar: majenfaৎf wi misțâr mahmuud fandu ha? la?in dârâgât Pahmad fi Pađer ?emtahaan kaanit wehfa

"This won't do and Mr. Mahmoud is right because Ahmed got a bad mark in the last test."

3- Ashraf: howwa laazim jegiib Peldârâgâ Pelneha?ejja Galafaan mostawaa majeb?aa ḍ̂âiiif wi biṣârâhâ Pelmodarres da Pisterlaali

"Must he get the full mark so as not to be considered weak? And frankly, this teacher is a profiteer."

4- Samar: bas howwa Jââter wi Gaajez jehasin mostawa Pahmad mif la?enu bijhebu wa ?enama laPinu hâriiṣ Pin țâlâbtu jegiibu dârâgâât Salja fi PelPemtahaan fafaan jehââfiz Cala somfetu

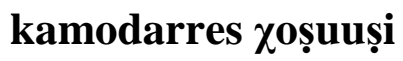


"But he's clever and wants to improve Ahmed's level not because he likes him but because he's keen on making his students get high marks in the final exam as he wants to keep his reputation as a private teacher."

In extract (30), Samar, the wife, expresses her disagreement with Ashraf, her husband, by justifying the Arabic teacher's attitude twice. The first is in line 2 when she refuses the suggestion her husband makes in line 1 when he tells her to let the teacher move their son to a different group. She rejects the idea and provides a reason in which she justifies the teacher's attitude by saying that the teacher is right since their son's mark was weak. But when Ashraf challenges her in line 3, she disagrees with him once more in line $\mathbf{4}$ by justifying the teacher's attitude saying that the teacher is keen on making his students get high marks in the final exam because he wants to keep his good reputation as a private teacher.

Anti-target disagreement strategies involve making negative evaluations about the target and criticizing him/her. The strategies are found in extracts (31) and (32): 
Extract (31)

1- Freddie: Calm down, we didn't buy anything from him anyway.

2- Kate: Because he was so hard-headed and wouldn't cut down the price of anything we wanted to buy.

3- Freddie: But he was welcoming.

4- Kate: No, he wasn't genuine. He's a clever actor.

5- Freddie: He's a clever guy and was simply trying to sell us some souvenirs.

6- Kate: You mean he was trying to force us to buy some exceptionally expensive and not very special souvenirs. You are easily deceived by appearances.

7- Freddie: Not true, my dear. I just take things easy. You're taking it too hard.

8- Kate: You didn't see his nasty reaction when we walked away without buying anything.

9- Freddie: What did he do?

10- Kate: He changed his seemingly nice way of treating tourists and pulled a face and murmured and pouted. 
In this extract, when Freddie tries to calm Kate down in line 1 by telling her that they did not buy anything from his bazaar, she says that the reason for this is that the seller, who she believes to be greedy, was so "hard-headed" as he "wouldn't cut down the price of any souvenir." Furthermore, when in line 3 Freddie says that the seller was "welcoming", she disagrees with him in the next line by negatively evaluating the seller and saying "he wasn't genuine. He's a clever actor." Kate also criticizes the seller in line 6 in response to Freddie's defense of him in the previous line. Moreover, Kate keeps trying to convince Freddie that the seller is not a nice person as he thinks and she does so by criticizing his-the seller's-attitude in line 8 by saying that he reacted in a nasty way when they did not buy anything from him. When Freddie inquires about the seller's reaction in line 9, she replies in the next line by criticizing his-the seller's-attitude.

\section{Extract (32)}

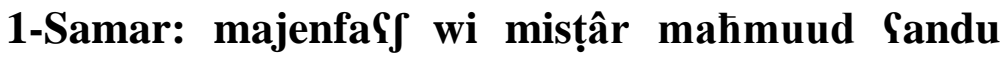

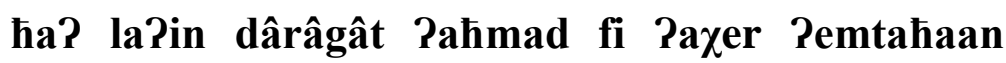
kaanit wehfa 
"This won't do and Mr. Mahmoud is right because Ahmed got a bad mark in the last test."

2-Ashraf: howwa laazim jegiib Peldârâgâ Pelneha?ejja Salafaan mostawaa majeb?aa\} ḍ̂âiif wi biṣârâhâ Pelmodarres da Pisterlaali

"Must he get the full mark so as not to be considered weak? And frankly, this teacher is a profiteer."

3-Samar: bas howwa Jâațer wi Caajez jehasin mostawa Pahmad mif la?enu bijhebu wa ?enama la?inu hâriiṣ Pin țâlâbtu jegiibu dârâgâât Salja fi PelPemtahaan Gafaan jehââfiz fala somfetu kamodarres qoṣuuṣi

"But he's clever and wants to improve Ahmed's level not because he likes him but because he's keen on making his students get high marks in the final exam as he wants to keep his reputation as a private teacher." 


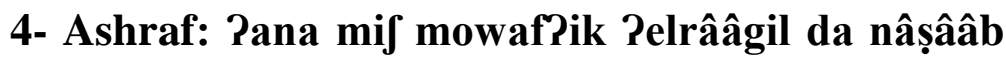
kol Jowajja jeSmel Pemtahanaat wi jeddi Peltâlâbâ dârâgâât ḍâfiifa wi je?uul lilPahaali Pin weladhom mehtagiin heșâṣ zejaada

"I don't agree. This guy is a swindler; every now and then he examines the students, gives them bad marks and tells the parents that their kids need extra lessons."

In this extract, when Samar defends Mr. Mahmoud-the Arabic teacher-in line 1, Ashraf replies in line 2 by making a negative evaluation of the teacher by describing him as a "profiteer". He also describes the teacher as a "swindler" in line 4 in response to his wife's defense of the teacher in line 3. Ashraf also criticizes Mr. Mahmoud in line $\mathbf{4}$ when he says that the teacher "examines the students, gives them bad marks and tells their parents that their kids need extra lessons."

The data of adults' speech has revealed that two disagreement strategies are used regardless of whether the speaker is pro or anti the target. The two strategies are: the use of explicit indicants of disagreement and criticism of the other speaker in the gossip episode. Extracts (33) and (34) clarify the first strategy: 


\section{Extract (33)}

1- Freddie: But the prices of the other stuff in the bazaar were ok.

2- Kate: I don't see this.

3- Freddie: And I don't see that his prices are very different from those of the sellers in the other bazaars.

In extract (33), both Freddie, who is pro the target, and Kate, who is anti the target, use explicit indicants of disagreement and criticize each other. In line 1, Freddie says that "the prices of the other stuff in the bazaar were $o k$ " but Kate disagrees with him in line 2 using the phrase "I don't see this" and Freddie uses the same phrase, which explicitly indicates disagreement, to disagree with her in line 3 and says "I don't see that his prices are very different from those of the sellers in the other bazaars."

\section{Extract (34)}

1-Samar: bas howwa fâațer wi Caajez jehasin mostawa Pahmad mif la?enu bijhebu wa ?enama laPinu hâriiṣ Pin țâlâbtu jegiibu dârâgâât Yalja fi 
PelPemtahaan Gafaan jehââfiz Gala somfetu kamodarres qoṣuuṣi

"But he's clever and wants to improve Ahmed's level not because he likes him but because he's keen on making his students get high marks in the final exam as he wants to keep his reputation as a private teacher."

2- Ashraf: Pana mið mowafiik Pelrââgil da nâșââb kol Jowajja jeSmel Pemtahanaat wi jeddi Pelțâlâbâ dârâgâât ḍ̂âiiifa wi je?uul lil?ahaali ?in weladhom mehtagiin heṣậ zejaada

"I don't agree. This guy is a swindler; every now and then he examines the students, gives them bad marks and tells the parents that their kids need extra lessons."

3- Samar: da mif ṣâhiih Pelli bijehṣâl Pin fi țâlâbâ bitgiib dârâgâât ḍâfiifa bas kamaan fi bigiibu dârâgâât kowajjesa ?awi 
"This is not true. What happens is that some kids get weak marks but there are also those who get very good marks."

In this extract, when in line 1 Samar defends the Arabic teacher and justifies his attitude, Ashraf disagrees in line 2 using the phrase "I don't agree" then he makes a negative evaluation of the teacher and criticizes his attitude. But Samar explicitly disagrees in line 3 saying "This is not true."

The second disagreement strategy is clarified in extracts (35) and (36) below:

\section{Extract (35)}

1- Freddie: But he was welcoming

2- Kate: No, he wasn't genuine. He's a clever actor.

3- Freddie: He's a clever guy and was simply trying to sell us some souvenirs.

4- Kate: You mean he was trying to force us to buy some exceptionally expensive and not very special souvenirs. You are easily deceived by appearances.

5- Freddie: Not true, my dear. I just take things easy. You're taking it too hard. 
In extract (35), when Freddie says that the seller was "welcoming", Kate disagrees in line 2 using the explicit indicant of disagreement "No". Freddie also disagrees with Kate in line 5 using the phrase "Not true" in response to her criticism of him in line 4 in which she says that he is "easily deceived by appearances." Not only does Freddie disagree with Kate's criticism of him but also criticizes her saying "you're taking it too hard."

\section{Extract (36)}

1- Ashraf: Penti methamesaalu gidan ka?in mafiif modarres zaju ma Pelmodaresiin Pelkowajjesiin kitiir

"You're an ardent supporter of him as if there's no teacher like him. There are so many good teachers."

2- Samar: Pelmodaresiin Pelkowajjesiin kitiir bas Pelmodarres da somৎetu kowajjesa Pawi wi baSdeen Penta motahaamil Saleeh gidan 
"There are so many good teachers but this one has a very good reputation. You're not fair to the guy."

In this extract, Ashraf and Samar criticize each other. In line 1, Ashraf does not like the fact that his wife is on the teacher's side and criticizes her saying "You're an ardent supporter of him as if there's no teacher like him." Samar then makes a positive evaluation of the teacher and criticizes her husband in line 2 telling him that he is unfair to the teacher.

By comparing the gossip episodes of adolescents and adults, it becomes clear that there are some similarities and differences in the strategies of gossip used by adolescent and adult Egyptians and native English speakers. Both adolescents and adults make suggestions, criticize the other speaker, defend the target of gossip, and make positive evaluations of him/her on the part of the speakers who are on the target's side. Moreover, adolescents and adults make negative evaluations of the target directly and explicitly. However, as shown in examples (13) and (14), negative evaluations in adolescents' speech also occur implicitly via sarcasm. 
Some differences have been observed in the strategies of gossip used by adolescents and adults. Religious comments have been found in the speech of adult Egyptians only and were absent from the speech of adolescent Egyptian speakers. In addition, unlike adolescents, adult speakers, whether they are pro or anti the target, use explicit indicants of disagreement and tend to criticize each other. The last difference is that while negative evaluations of the target are made by the initiators of the gossip episodes in the speech of adolescent Egyptians and native English speakers, they are sometimes made by the other participants, rather than the initiators of gossip, in the speech of adults, whether Egyptians or native English speakers.

\subsubsection{Structure of Adult Gossip}

The structure of adult gossip in the present study bears some resemblance to the structure of gossip given in Eder and Enke's study but there are some differences. For example, in Eder and Enke's study a gossip episode starts by identifying a target then expanding the identification, making either a positive or negative evaluation of the target, or requesting a 
clarification. This structure of the beginning of a gossip episode is found in conversations (7), (10), and (11) (see Appendix B). In conversation (7), Suzy identifies her mother-in-law as the target of gossip in turn 6 when she tells Amira that "She's the cause of all problems" and negatively evaluates her by describing her as a "devil". In conversation (10), Lesley identifies Steve-Dorothy's ex-husband- as the target of gossip in turn 3 and makes a negative evaluation of him by describing him as a "misfit". In conversations (11), Kate identifies the seller as the target of gossip in turn 3 and describes him as "greedy".

The beginning of the gossip episode in conversations (8), (9), and (12) is structured differently (see Appendix B). In conversation (8), Dr. Ayman identifies his colleague, Dr. Mohamed, as the target of gossip in turn 1 but the identification is not followed by an expansion of the identification, an evaluation of the target or a request for clarification. Rather, it is followed by a comment which implies that the tearget did something that was not liked by the speakers. Then there is a narrative that explains the target's attitude and Dr. Ayman's reaction. The first evaluation of the 
target, Dr. Mohamed, is made in turn 12 by Dr. Yehia based on what he heard from Dr. Ayman, then he-Dr. Yehia-makes another negative evaluation of Dr. Mohamed in turn 14 again based on what Dr. Ayman told him concerning Dr. Mohamed's attitude. The last evaluation, which is negative, is made by Dr. Ayman, the initiator of the gossip, in turn 16.

In conversation (9), in which the two speakers disagree with each other, it is Ashraf, rather than Samar, who initiates the gossip. This is because when Samar informs her husband that Mr. Mahmoud-the Arabic teacher- wants to give their son's group extra private lessons, he replies in turn 3 by making a negative evaluation of the teacher. In other words, Samar did not mean to identify the teacher as a target of gossip. Rather, it is Ashraf who makes him the target by the negative evaluation he makes in turn 3 . This derives Samar to start defending the target then a sequence of challenges and counter challenges follow.

In conversation (12), Barbara identifies her son as the target of gossip in turn 2 but the identification is not followed by any of the acts found in Eder and Enke's study. Rather, it is again followed by a comment that 
shows understanding on the part of Jackie of how Barbara feels. Throughout the episode, Barbara gives details about what worries her concerning her son. The first and only time an evaluation is made of Mark is in turn 11 in which Jackie says that he is "becoming a troublemaker" when Barbara tells her that he "started to be aggressive and rude with the kids in school". In other words, as in conversation (10), the hearer is the one who makes an evaluation of the target based on what is said by the initiator of the gossip.

It has been found that the possible acts in response shown in figure (1) are slightly different in adult gossip. This is because in Eder and Enke's study, the acts given in figure (1) follow the evaluation of the target which in turn follows the identification. In other words, according to Eder and Enke, the identification of the target occurs first followed by an evaluation then the evaluation is followed by the acts shown in figure (1). As mentioned above, in adults' speech, the identification of the target is not always followed by an evaluation. Therefore, in the present study, these acts can occur after the identification of the target and not after the evaluation. In addition to some of the acts given by Eder 
and Enke, conversations (7), (8), (10), (11), and (12) include other acts, namely making comments, whether evaluative, supportive, or religious, inquiring about the speaker's/target's attitude/reaction, expanding the explanation, and requesting a clarification of the explanation. The structure of adults' speech can be represented as shown in figure (2): 


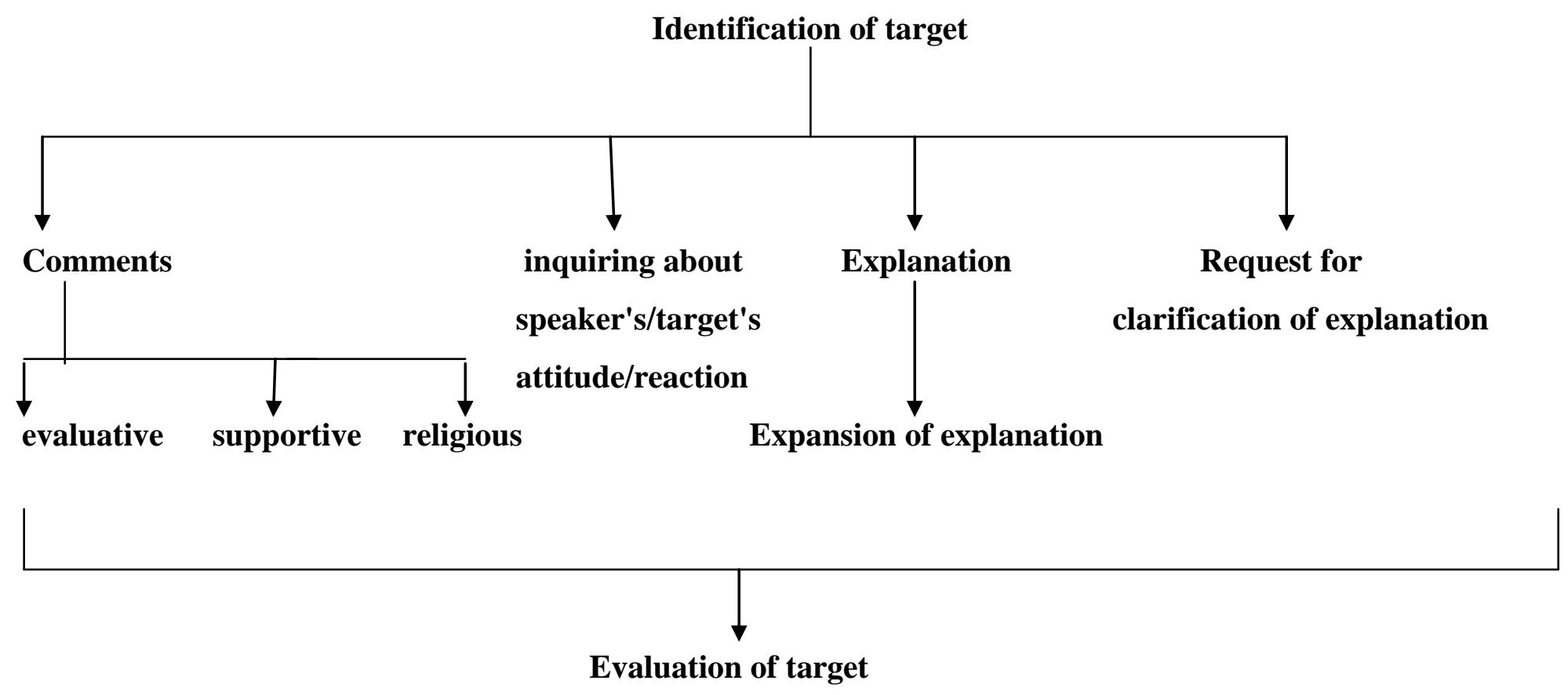

Figure (2): The Structure of Adult Gossip 
Figure (2) shows that a gossip episode in the speech of adult speakers can start by identifying the target but the identification is not followed by an evaluation of the target. Rather, it is followed by a number of acts that lead to making an evaluation of the target. In other words, an evaluation of the target is made based on the detailed information about him/her given in the gossip episode. This structure is illustrated in the following extracts:

\section{Extract (37)}

1- Suzy: mabâțâlif nâqd lil?akl wi tanḍiifi lilbeet wi fosli hatta dalaYi liwlaadi mi Sagibha

"She kept criticizing everything; my cooking, cleaning of the house, and my job. She didn't even like the way I pamper my kids."

2- Amira: Geeb Salehaa

"Shame on her"

3- Suzy: we tisada?i bit?olu howwa Pelli beteSmelu da Pakl walla da tanḍiif hejja leeh bitftasal di Samlak dada lamma teruuh ?elforl 
"And she tells him 'Is this food? Is this cleaning? Why does she work? She makes you a babysitter when she goes to work.' Can you believe it?"

4- Amira: mâjṣâhij te?uul keda

"She shouldn't say this."

5- Suzy: wi kamaan bit?olu Peni Paৎat ९ala Pelkorsi wi râfâft regli Yala Peltarâbeeza fi weJha

"She also tells him that I sat on the chair and put my leg on the table before her face."

6- Amira: wi da kalaam had jesada?u di keda betwa Pa beenik wi beenu wi betexreb ?elbeet

"Nobody would believe this talk. She's driving a wedge between you and your husband and destroying the house."

In extract (37), Amira makes evaluative and religious comments in response to what Suzy tells her about her mother-in-law. In lines 1 and 3, Suzy gives detailed explanations of what her mother-in-law did 
that made her husband-Medhat-change his attitude. Amira replies in lines 2 and 4 by making evaluative comments concerning the attitude of Suzy's mother-inlaw. In line 5, Suzy expands the explanation and Amira replies in line 6 by making an evaluative comment not on the attitude of the target but on the target herself, i.e. Suzy's mother-in-law, telling Suzy "She's driving a wedge between you and your husband and destroying the house."

\section{Extract (38)}

1- Lesley: Well, she's the one to blame. What could a woman like in a man like Steve? I just don't get it. He was a real misfit.

2- Margaret: True. Personally, I always thought so and never actually liked him.

3- Lesley: But you never said anything. Don't you think that's strange?

In line 2, Margaret makes a supportive comment in response to what Lesley says in the previous line. In line 3, Lesley inquires about Margaret's attitude as she- 
Lesley-is surprised that Margaret did not ever say that she did not like her daughter's ex-husband.

\section{Extract (39)}

1- Dr. Ayman: la? Samal mâwqif taani małaaja Pana fâș̣ejan kont lessa badi? mohâḍreti wi fag?a la?eet doktoor mehamad bijzâbât Yalajja wije?olli Penni waaxid Pelqâfâ betaStu

"No, he did another thing with me personally. I was just starting my lecture and suddenly the door knocked and it was Dr. Mohamed telling me that I've taken his hall."

2-Dr. Yehia: Pizzaj hejja mif qâfâât Pelmohâṭârâât metwazała Sala Pel?âqsaam min Pawil Pelterm howwa dajman keda $\chi$ aalif tofraf

"How is that? Aren't the lecture halls distributed among the departments from the beginning of the term? He always acts differently from others."

3- Dr. Ayman: belụâbt keda

"Exactly" 
4- Dr. Yehia: wi Gamalt Peeh

"And what did you do?"

5- Dr. Ayman: Poltelu Pin Pelqâfâ betafti binaa?an Sala tawziiß Pelqâfâât Pelli Pettafa?at Saleeh kol Pel?âqsaam fi Pel?igtemaৎ Pelli Samalu wikiil Pelkolleja lefo?uun Pelțollâb wi Pin qesmu howwa Pelqesm Pelwahiid Pelli mahâḍârf momasiliin Sannu

"I told him that the hall is mine according to the distribution that was decided upon by all the departments in the meeting held by the vice dean for students' affairs. I also told him that his department was the only one from which there were no representatives in the meeting."

When, in line 1, Dr. Ayman explains Dr. Mohamed's attitude, Dr. Yehia requests a clarification for the explanation in line 2. After Dr. Ayman answers in line 3, Dr. Yehia inquires about his-Dr. Ayman'sattitude with the target in the next line. In line 5, Dr. Ayman expands the explanation. 
Extract (40)

1- Dr. Yehia: wi kaan ?eeh râd feYlu

"And what was his reaction?"

2- Dr. Ayman: Palli Penu maaji Gala Peltawzii ?elli mâtâa Yaleeh PelSamiid Pabl keda

"He told me that he is following the distribution that the dean signed before."

3- Dr. Yehia: da fâxṣ mostafiz ?eltawziị ?elPadiim da mif moqâddâs wi momkin jetкâjjâr

"He's a provocative person. The old distribution is not holy and can be changed."

4- Dr. Ayman: ma Pana lamma Poltelu Pin Peltawziiß Petrâjjâr laPetu bijPuul lelțâlâbâ bituufu Po?afu Poddaam maktab wikiil Pelkolleja lefo?uun Pelṭollââb wi Pef̣̂alu wa?fiin hinaak lehad ma jehel ?elmofkela wi law Peljoom Pentaha min seer Pelmofkela tethal hanaxod Pelmohâậâ PelPosbuuৎ Pelgaj filțor?a Pelli Poddam Pilqâfâ betaSetna 
"When I told him that the distribution has changed, he told his students to go and stand in front of the office of the vice dean for students' affairs and to remain standing there till the problem is solved, and if, by the end of the day, the problem is not solved, they'll take the lecture in the corridor in front of the hall."

5- Dr. Yehia: Peeh da tâhriị̣ șâriih da Pakiid

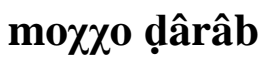

"What? This is clear instigation. He must have lost his mind."

6- Dr. Ayman: bijetẓââhir be?enu Jâxṣ sawragi wi bejdâwwâr Cala ha?u Paw Pelli howwa fakir ?enu ha?u

"He pretends to be a rebellious person who is looking for his right or rather what he thinks is his right." 
7- Dr. Yehia: beкâd Pelnâzâr San kono ha?u Paw mif ha?u howwa mif Saarif Pin Postaaz Pilgam qodwa

"Regardless of what is or is not his right. Doesn't he know that a university professor is an example?"

8- Dr. Ayman: da majẹrâff haaga San Pelqodwa wi Pelqejam PelgameSejja

"He knows nothing about exemplary behavior and university values."

9- Dr. Yehia: Yeeb Pawi Pelli Yamalu da

"What he did is so disgraceful."

10- Dr. Ayman: râbena jehdi

"May God grant him guidance."

In line 1, Dr. Yehia inquires about the target's reaction and when Dr. Ayman provides an explanation in line 2, Dr. Yehia replies in line 3 by making an evaluative comment about the target describing him 
"provocative," and the topic, which is the distribution of lecture halls among the departments in the faculty, describing it as "not holy and can be changed." In line 4, there is another expansion of explanation followed by evaluative comments about the target in lines 5 and 6 and of his-the target's-attitude in lines 8 and 9. Then in line 10, Dr. Ayman ends the gossip episode by making a religious comment.

\section{Extract (41)}

1- Ashraf: wi natiiget Penu bijoffot Pelfeluus min Pelțâlâbâ Penu raakib Sârâbejja gidiida Pahdas haaga

"And the result of absorbing money from the students is that he has a new car that's of the latest model."

2- Samar: Pel?arzaa? di min râbena

"Blessings are from God."

In extract (41), when Ashraf tells his wife in line 1 that Mr. Mahmoud- the Arabic teacher- has a brand new car which he managed to buy because he takes a lot of money from his students, she answers in line 2 by 
making a religious comment as she says "Blessings are from God."

In conversation (12), all the comments made by Jackie are supportive as she wants to show sympathy and understanding of how her friend, Barbara, feels because of the hard time her son, Mark, is giving her and of how Mark himself feels after he lost his father.

Like adolescents' speech, adults' speech can include making suggestions to offer solutions for problems. This act is found in extracts (42) and (43) below:

\section{Extract (42)}

1- Barbara: I don't know what to do.

2- Jackie: Why don't you make him see a psychiatrist?

In extract (42), when Barbara says she does not know what to do with her son, Mark, whose attitude changed after he lost his father, Jackie, in line 2, makes a suggestion to her friend and tells her to make him see a psychiatrist. 
Extract (43)

1- Samar: bij\}uul Pin Peltâlâbâ fi magmuufet Pahmad mostawaahom ḍ̂fiif wi mehtagiin jetmârânu zejaada

"He says that students in Ahmed's group are weak and need to practice more."

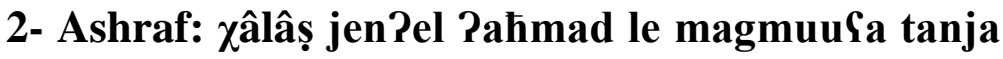
mostawaha Pahsan min Pelmagmuufa Pelli howwa fiiha

"Then tell him to move Ahmed to another group that's better than the one he's in now."

In extract (43), Ashraf does not like it when his wife tells him that the Arabic teacher wants to give their son's group extra private lessons. When Samar tells her husband, in line 1, that the teacher says that the level of their son's group is weak and that the students in this group need to practice more, he, thinking that their son is doing fine in Arabic, suggests, in line 2, making the teacher move their son to another group whose level is better than the one he is in. 
Although making suggestions is common between adolescents and adults, in adolescents' speech, suggestions are made by speakers who are not familiar with the target whereas in adults' speech, suggestions are made by speakers who are familiar with the target. However, in adolescents' as well as in adults' speech, suggestions are made for the same reason, namely offer solutions to problems.

\section{Conclusion}

This study examines the effect of age on the structure and strategies of gossip in the speech of adolescent and adult Egyptians and native English speakers to highlight similarities and/or differences in the strategies employed when gossiping as well as similarities and/or differences in the strategies of gossip found in their speech.

It has been found that some strategies are used more by adolescent Egyptians while others are used more by adolescent native English speakers; adolescent Egyptians challenge the evaluation of the target and use sarcasm to implicitly and negatively evaluate the target more than adolescent native English speakers. Partial 
agreement and making suggestions are used more by adolescent native English speakers than by aadolescent Egyptians. There is no difference in the frequency of using the strategy of topic change in the speech of both adolescent Egyptians and native English speakers.

Some similarities, but no differences, have been noticed in the strategies used by adolescents, whether they are Egyptians or native English speakers, when gossiping. One similarity is that shared knowledge of the target, or lack of it, has an effect on the strategies used in the gossip episode; when all group members have shared knowledge of the target, they employ similar strategies, namely partial agreement, topic change, and challenging the evaluation which takes place by defending the target, asking a question to elicit agreement, criticizing the other speaker, and making a positive evaluation of the target. However, when only the initiator of the gossip knows the target well and the other group members have insufficient knowledge of the target, adolescents, whether Egyptians or native English speakers, use the strategy of making suggestions. Although using sarcasm to implicitly evaluate the target was found in adults' speech in 
Hallett, Harger, and Eder's study, in the present study, this strategy has been found in the speech of adolescent Egyptians and native English speakers who use it regardless of whether group members have shared knowledge of the target or not.

The structure of adolescents' gossip in the present study is similar to the structure given by Eder and Enke in their study. However, one difference is noted between adolescent Egyptians and native English speakers concerning challenging as a possible act in response. Similar to Eder and Enke's study, challenging occurs right after an initial evaluation of the target is made in the speech of adolescent native English speakers. In the speech of adolescent Egyptians, on the other hand, challenging does not necessarily occur after the initial negative evaluation.

Adult Egyptians and native English speakers employ several strategies when gossiping but some strategies are used more by adult Egyptians while others are used more by adult native English speakers. Adult Egyptians finish each other's utterances, make positive evaluations about the target, criticize the target and make religious comments more than adult native 
English speakers. The latter use explicit indicants of agreement, justify the target's attitude and criticize the other speaker more than adult Egyptian speakers. The frequency of using exclamatory questions, facilitative questions, explicit indicants of disagreement and making negative evaluations about the target is the same in the gossip episodes of both adult Egyptians and native English speakers.

The data reveals that adults' speech, unlike adolescents' speech, reflects a high degree of involvement that is seen in the cooperative gossip strategies used. These strategies, which are employed by adult Egyptians and native English speakers, are: speakers finishing each others' utterances, using explicit indicants of agreement, and using exclamatory as well as facilitative questions. When adult Egyptians and native English speakers disagree with each other, they tend to use certain gossip strategies to express this disagreement. These strategies are either pro or anti the target. Pro-target disagreement strategies are: making positive evaluations about the target and justifying his/her attitude. Anti-target disagreement strategies are: making negative evaluations about the target and 
criticizing him/her. It has also been found that using explicit indicants of disagreement and criticizing the other speaker in the gossip episode are two disagreement strategies that adult Egyptian and foreign speakers use regardless of whether the speaker who disagrees is pro or anti the target. Except for the tendency of adult Egyptian speakers to use religious comments, no differences in the strategies of gossip between adult Egyptians and native English speakers are found.

Adolescent and adult Egyptians and native English speakers use similar strategies when gossiping. These are: making suggestions, criticizing the other speaker, defending the target by justifying his/her attitude and making positive as well as negative evaluations of the target. However, there are also some differences in the gossip strategies used by adolescents and adults. Religious comments are made by adult Egyptians only. Moreover, adult speakers, rather than adolescents, use explicit indicants of disagreement and criticize each other. Furthermore, while the initiators of the gossip episodes in the speech of adolescents, whether Egyptians or native English speakers, make negative 
evaluations of the target, group members, other than the initiators of the gossip episodes, are the ones who make negative evaluations of the target in the speech of adult speakers, whether Egyptians or native English speakers.

The structure of adults' speech bore some resemblance to Eder and Enke's structure in that the identification of the target is sometimes followed by an evaluation of the target. However, it has been found that in adults' speech, an evaluation of the target does not always follow his/her identification. Rather, the identification can be also followed by a number of acts, namely comments, inquiries about the speakers'/target's attitude/reaction, explanation, expansion of explanation, and request for clarification of explanation.

Because the present study examines the impact of age only on the strategies and structure of gossip, the findings are not exhaustive. There are other variables that may influence one's propensity to gossip and thus have an impact on the strategies and structure of gossip. These variables include: group structure, social class, gender, setting, topics and power relations. Therefore, 
future research on naturally-occurring gossip could investigate the role played by these variables in shaping the structure of gossip episodes and determining the strategies used. Future research could also look at the role of gossip in social relationships by examining this momentous phenomenon in Internet blogs and social networking sites like Twitter and Facebook, and studying how gossip is perceived by different respondents and the factors that determine their response.

Studying the strategies and structure of gossip helps understand how speakers, whether adolescents or adults, cooperate in creating the gossip and participate in it. Thus, gossip should not be viewed as idle talk. Rather, it is a collaborative and interactive activity that performs social functions and fosters group bonds. 


\section{References}

Ben-Ze'ev, A. (1994). The Vindication of Gossip. In Robert F. Goodman \& Aharon Ben'Ze'ev (Eds.), Good Gossip (pp. 11-24). Lawrence, KS: Univesity of Kansas Press.

Brown, M.E. (1990). Motley Moments: Soap Operas, Carnival, Gossip and the Power of the Utterance. In Mary E. Brown (Ed.), Television and Women's Culture: The Politics of the Popular. Communication and Human Values (pp. 183-198). Thousand Oaks: Sage.

Coates, J. (1988). Gossip Revisited: Language in All-Female Groups. In Jennifer Coates \& Deborah Cameron (Eds.), Women in their Speech Communities: New Perspectives on Language and Sex (pp. 94-122). London: Longman.

Cuonzo, M.A. (2008). Gossip: An Intention-Based Account. Journal of Social Philosophy, 39(1), 131-140.

DiFonzo, N., \& Bordia, P. (2007). Rumor Psychology: Social and Organizational Approaches. Washington, DC: American Psychological Association. 
Dunbar, R. I. M. (1992). Why Gossip is Good for you? New Scientist, 21, 28-31.

Dunbar, R. I. M. (2004). Gossip in Evolutionary Perspective. Review of General Psychology, 8(2), 100110.

Eder, D., \& Enke, J. L. (1991). The Structure of Gossip: Opportunities and Constraints on Collective Expression among Adolescents. American Sociological Review, 56(4), 494-508.

Eggins, S., \& Slade, D. (1997). Analyzing Casual Conversation. London: Cassell.

Foster, E. K. (2003). Researcging Gossip with Social Network Analysis (Doctoral dissertation). Available from ProQuest Dissertations and Theses database (UMI No. 3112272)

Foster, E. K. (2004). Research on Gossip: Taxonomy, Methods, and Future Directions. Review of General Psychology, 8(2), 78-99.

Goodwin, M. H. (1980). He-Said-She-Said: Formal Cultural Procedures for the Construction of a Gossip Dispute. American Ethnologist, 7(4), 674-695. 
Grosser, T., Lopez-Kidwell, V., \& labianca, G. (2010). A Social Network Analysis of Positive and negative Gossip in Organizational Life. Group \& Organization Management, 35(2), 177-212.

Hafez, O. M. (1991). Turn-taking in Egyptian Arabic: Spontaneous Speech vs. Drama Dialogue. Journal of Pragmatics, 15, 59-81.

Hallett, T., Harger, B., \& Eder, D. (2005, August). Strategies of Adult Gossip. Paper presented at the Ethnomethodology and Conversation Analysis Section Session at the American Sociological Association Meetings. Philadelphia, PA.

Hambaugh, J. L. (2011). Gossipmongers: Interest in Gossip as a Function of Gender and Mode of Transmission (Doctoral dissertation). Available from ProQuest Dissertations and Theses database (UMI No. 3486970)

Holland, M. G. (1996). What's Wrong with Telling the Truth? An Analysis of Gossip. Philosophical Quarterly, 33(2), 197-209.

Holmes, J. (1995). Women, Men and Politeness. London: Longman. 
Jaworski, A., \& Coupland, J. (2005). Othering in Gossip: "You Go out You Have a Laugh and you can Pull Yeah Okay but Like..." Language in Society, 34(5), 667-694.

Johnson, S. (1994). A Game of Two halves? On Men, Football and Gossip. Journal of Gender studies, 3(2), 145-154.

Jones, D. (1980). Gossip: Notes on women's Oral Culture. In Deborah Cameron (Ed.) Feminist Critique of Language. London: Routledge.

Kurland, N. B., \& Pelled, L. H. (2000). Passing the Word: Toward a Model of Gossip and Power in Workplace. The Academy of Management Review, 25(2), 428-438.

Kuttler, A. F., parker, J. G., \& la Greca, A. M. (2002). Development and Gender Differences in Preadolescents' Judgments of the Veracity of Gossip. Merril-Palmer Quarterly, 48, 105-132.

Labov, W. (1972). Language in the Inner City: Studies in the Black English Vernacular. Philadelphia, PA: University of Pennsylvania Press. 
Michelson, G., van Iterson, A., \& Waddington, $\mathrm{K}$. (2010). Gossip in Organizations: Contexts, Consequences, and Controversies. Group \& Organization Management, 35(4), 371-390.

Nevo, O., Nevo, B., \& Derech-Zehavi, A. (1993). Gossip and Counselling: The Tendency to Gossip and its Relation to Vocational Interest. Counselling Psychology Quarterly, 6(3), 229-238.

Pilkington, J. (1998). 'Don't try and make it out that I'm nice!' The Different Strategies Women and Men Use when Gossiping. In Jennifer Coates (Ed.), Language and Gender: A Reader (pp. 254-269). Oxford: Blackwell.

Rysman, A. (1977). How the "Gossip" Became a Woman. Journal of Communication, 27(1), 176-180.

Spacks, P. M. (1982). In Prasie of Gossip. The Hudson Review, 35(1), 19-38.

Tannen, D. (1990). You Just Don't Understand: Women and Men in Conversation. New York, NY: Morrow. 
Tebbutt, M., \& Marchington, M. (1997). "'Look Before You Speak': Gossip and the Insecure Workplace." Work, Employment, \& Society, 11, 713-735.

Warber, K. M. (2004). The Role of Interpersonal Jealousy in Gossip: An Evolutionary Perspective (Master's thesis). Retrieved from

http://www.msubillings.edu/CommFaculty/Coffman/410\% 20online/readings/gossip.pdf 


\section{Appendix A: Transcription Conventions}

[ interrupted speech

Italics emphasis

\section{Symbols Used in the Transcription of Arabic}

The phonemic symbols used in the transcription of Arabic are adapted from IPA and El-Menoufy (as cited in Hafez, 1991: 79-80).

\section{Consonants}

The consonant symbols used to transcribe Arabic are those of IPA since they have similar values to those used to represent English sounds. These consonants are

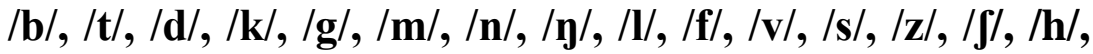
$/ \mathbf{w} /, / \mathbf{r} /, / \mathbf{z} /$, and $/ \mathbf{j} /$. The sounds below are peculiar to the Arabic language:

/q/ a uvular voiceless plosive, as in 'qâ?id' (leader)

/?/ a glottal stop, as in 'Pamal' (hope)

/ъ/ a voiced fricative, as in 'ъâjuur' (jealous) 
$\mid \chi /$ a voiceless fricative, as in ' $\chi 00 f^{\prime}$ (fear)

$/ \partial /$ a pharyngeal voiced fricative, as in ' $\partial$ ajn' (eye)

/h/ a pharyngeal voiceless fricative, as in 'hekaaja' (story)

The following consonants are pharyngealized or velarized:

/ț/ as in 'ṭ̂abiib' (doctor) /ạ/ as in 'ḍohr' (noon)

/ṣ/ as in 'ṣ̂âzb' (difficult) / /̣̣/ as in 'zoruuf' (circumstances)

Vowels

The study uses six IPA short vowel symbols. These are:

/â/ as in 'dârâgâ' (mark) /a/ as in 'fataha' (he opened)

/e/ as in 'bent' (girl)

/i/ as in

'Palami' (my pen) 
$/ u /$ as in 'kanuu' (they were)

/o/ as in 'mojkela' (problem)

The length of long vowels is indicated by doubling the symbols as follows:
/aa/ as in 'saali' (expensive)
/oo/ as in
'loom' (blame)
/ee/ as in 'feen' (where?) /ââ/ as in 'mââdi' (past)
/ii/ as in 'kibiir' (big)
/uu/ as in
'dejuun' (debts) 


\section{Appendix B: Transcripts \\ Adolescent Egyptian Speakers}

Conversation (1)

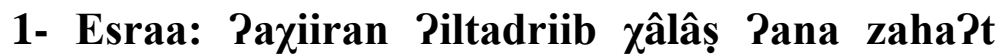
Pawi Pelnâhârdâ

"At last the practice is over. I was so bored today."

2- Basma: bilfaks Pana kont mostamtefa biltadriib Pelnâhârdâ

"On the contrary, I enjoyed the practice today."

3- Esraa: PestamtaSti bi Peeh wi țuul Pelwa?t Pelnâhârdâ Pelmodarrib Pelsaxiif da famaal jezaSaPlena

"Enjoyed what? The nasty trainer kept yelling at us today."

4- Basma: howwa kaan bijzafa? lelli kaanu kol Jowajja bijeৎmelu hârâkât sâlâț wi Gandu ha? la?in kol ћârâkâ fi Pelsebaaha laazim teb?a ṣâh

"He was yelling at those who made wrong movements, and he's right because every movement in swimming must be correct." 
5- Esraa: kallamik maẓbuut bas mi keda da kaan mezawedha Pawi Pana mi fahma howwa leeh Jaajef nafsu keda safaat

"That's correct but not in this way. He overdid it and I don't understand why he's so full of himself sometimes."

6- Basma: boș̣i howwa ṣâhiih safaat bijetkalim ketiir bas biṣârâhâ lamma bineSmil Pelhârâkât kollaha șâh bijfagafna walla tenkeri ?enu bijefmil keda

"Look, it's true that sometimes he talks a lot but honestly, he encourages us when we do the movements correctly. Do you deny that?"

7- Esraa: la? bas bârdu dammu te?iil ৎala Palbi wi

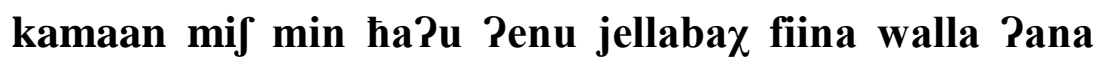
râlțâna

"No but still I don't like him, and also he has no right to scold us or am I mistaken?"

8- Basma: mafaaki ha? bas howwa mif bijjefmel keda Sâlâ țuul

"You're right but he doesn't do this all the time." 


\section{Conversation (2)}

1- Mona: doktor șấb Pawi Peeh Pelmawḍuu

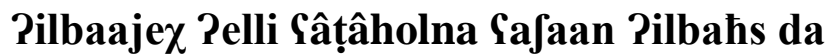

"Dr. Emad is so difficult. What's this uninteresting topic that he gave us for the research paper?"

2- Aya: Pajwa wi mif keda wi bas da kamaan

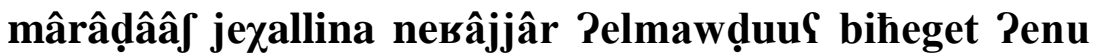

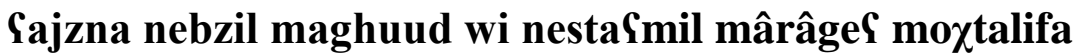

"Yes and not only this. He also refused to make us change the topic under the pretext that he wants us to exert an effort and use different references."

3- Mustafa: baajen Galeeh fakerna Pahmad zoweel fi zamaanu

"It seems he thinks we're Ahmed Zoweil."

4- Omar: mafiif mojkela Pen Pehna neftaral wi neţab Pahmad zoweel mawâșâlf lelli howwa fi bishuula walla Peeh?

"It's ok that we work really hard. Did Ahmed Zoweil reach such a high rank easily?"

5- Mustafa: la? bas mona wi Paya bijetkallemo ṣâh zoruuf Pahmad zoweel moxtalifa wi hâẓu Penu saafir 
Pamriika wi lawla PelPimkanijaat Pelli henaak makan $\int$ famjal haga

"No but Mona and Aya are right. Zoweil's circumstances were different. He was lucky enough to travel to America and hadn't it been for the facilities there, he wouldn't have been able to do anything."

6- Omar: bas PeltaSliim Pelmohtârâm Pelli Peţalemo fi mâșr saałed Sala nagahu fi Pamriika Peldoktor Sajzna netCalim begad

"And hadn't it been for the respectable education he received in Egypt, he wouldn't have travelled and succeeded in America. The doctor wants us to get good education."

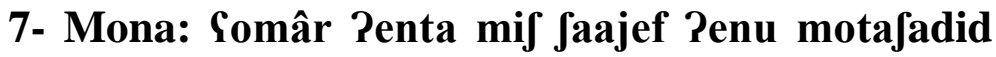
Pawi wi mi $\int$ marin

"Omar, can't you see that he's too strict and not lenient?"

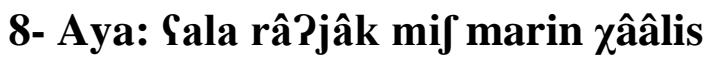

"You're right; he's not lenient at all."

9- Mustafa: wi Piidu naffa Pawii fi Peldârâgâât

"And he's not generous when it comes to marks." 
10- Omar: Pentu biteddalafu Pilmas?ala mif mas?alet Penu mif marin Paw Peedu naffa fi Peldârâgâât Peldoktor da ha??aani la?enu bijeddi kol țââlib ha?u Pelli jestaha?u bilzâbṭ wi Yala Pad ma Peftaral

"You're spoiled. It's not a matter of not being lenient or ungenerous with marks. The doctor is fair and gives every student his/her due depending on how much he/she worked."

11- Mona: wi howwa keda jeb?a misaali me keda

"And this makes him ideal, yes?"

12- Omar: țâbৎân misaali wi Gaadel laaPenu mif min Pelfadl Penu jesaawi been Pelli Peftasal we Pelli majtaralf

"Of course he's ideal and fair because it's not fair to treat those who worked hard and those who didn't work equally."

13- Mustafa: $\chi$ alluna nefuuf hanefmil Peeh fi Pilbahas

"Let's see what we'll do in the research paper."

14- Aya: Sandaak ha? jalla nebda? ?elforl 
"You're right. Let's get to work."

\section{Conversation (3)}

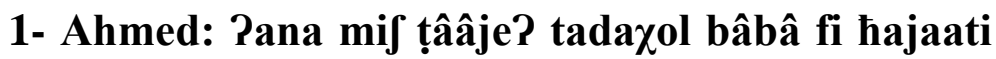
Pâktâr min keda

"I can't tolerate my father's interference in my life more than that"

2- Karim: haddi nafsak wi Polli Peeh Polli hâṣâl

"Calm down and tell me what happened"

3- Ahmed: bijohfor nafsu fi kol haaga texoșṣeni Pana Pitzana?t

"He interferes in everything that concerns me. I've had it."

4- Karim: Pakiid howwa Gaajez mâșlâhtak faadi zajjo zaj ?aj ?âb Paw Pom ma Yajziin mâṣlâhet weladhom walla Pana batkallem Paj kalaam

"He surely wants what's good for you just like all parents who want what's good for their kids. Am I talking nonsense?"

5- Ahmed: bas da mi maSnaa ?enu jedaxalni

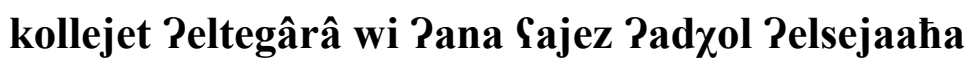


"But this doesn't mean that he makes me join the faculty of commerce although I want to join the faculty of tourism."

6- Karim: sarriba Penta Polteli Pabl keda Penu mowaafi? Pennak ted $\chi 0 l$ kollejet Pelsejaaha ?eeh Pelli hâsâal

"Strange, you told me before that he agreed to let you join the faculty of tourism, what happened?"

7- Ahmed: เâjjâr râ??ju fi joom wi lela

"He changed his mind over night"

8- Karim: leeh

"Why?"

9- Ahmed: Gajezni PasaSdu fi Peljerka lamma Pâtyârrâg

"He wants me to help him in the company when I graduate."

10- Karim: ?akiid Jaajef Pin keda Pahsan

"He surely believes that this is better."

11- Ahmed: bas bârdu howwa baltâân wi miđ șâh Penu jefreḍ Salajja haaga Pana mif Sajezha 
"But still he is mistaken and it is not right to force me to do something I don't want."

12- Karim: țâjjeb haawel tetkalem mafaa taani wi teqne\{u bi ra?jak wi Pesmå weghet nâzâru jemken waahed menkom je?dar jeqnes Peltaani bi weghet nâzâru Paw tewṣ̂alu lehal wâsât

"Ok, try to talk to him again and convince him of your opinion, and listen to his viewpoint. May be one of you will be able to convince the other of his viewpoint or you might reach a compromise."

13- Ahmed: mif hajgiib nattiga la?enu Senadi wi moṣâmim jexalliini Pa?adim wara?i fi ?eltegârâ

"This will be useless because he is stubborn and insists on making me present my papers in the faculty of commerce."

14- Karim: mif Saarif Pa?ollak ?eeh

"I don't know what to tell you."

15- Ahmed: maafiif haaga tet?aal howwa bijheb jeSmel Pelli howwa Jajfu șâh wi mið mohem Pelli Pana Gajzu Paw bahebu 
"There's nothing to be said. He likes to do what he believes is correct and what he wants, and it doesn't matter what I want or like."

\section{Adolescent Native English Speakers}

Conversation (4)

1- Maria: Hey guys, did you manage to do the Arabic homework well?

2- Kara: couldn't finish it.

3- Tom: Can't say I did it really well. I don't think any of us got the whole lecture but maybe [

4- Maria:

[may be the teacher didn't cover the lesson well.

5- Kara: No, I can't blame her. She did a good job. You're not being fair, Maria. Remember, you couldn't concentrate well the other day coz you weren't feeling well.

6- Maria: but she skipped some parts and I don't remember she made it clear why she did so. 
7- Tom: What you're saying isn't true. Sally is right; she said these parts weren't important but she explained everything else.

8- Kara: And she did a couple of exercises on the parts she explained.

9- Maria: True but most of our answers in class were incorrect.

10- Tom: But she explained why our answers were incorrect and said the correct ones.

11- Maria: Anyway let's just forget the homework and all this stuff. What's the plan for the weekend?

\section{Conversation (5)}

1- Emma: Glad it's break time.

2- Jane: Yeah

3- Emma: But what I need is not a break between classes. I need a break from Julia, my special roommate, my beloved roommate.

4- Jane: What do you mean?

5- Emma: I've had it with her. She's such a pain in the neck, a really messy person. 
6- Jane: Come on, tell me about it. I know, you told me before she's not very nice but messy? What happened?

7- Emma: She always leaves the place in a mess; the kitchen, the bathroom, the living room and the bedroom are all so untidy and messy. And whenever I tell her that we need to divide the labor and clean our flat at least once a week, she just says "we'll see". She's a real snob.

8- Jane: You know, I didn't like the way she behaved the day we went out for dinner. She was so snobbish.

9- Emma: And she always pretends to be a knowit-all.

10- Jane: Why don't you move out next term?

11- Emma: That would be a good idea.

\section{Conversation (6)}

1- Clara: I'm so down, Laura.

2- Laura: It shows on your face. What's up? 
3- Clara: Things are just getting worse between me and Tim. He's become so unbearable.

4- Laura: You didn't have another quarrel, did you?

5- Clara: It was nothing serious but it's just that we don't seem to be getting along anymore.

6- Laura: But you love him and you always said he was nice.

7- Clara: He is nice. The problem is that sometimes he acts in a strange way, you know.

8- Laura: How so?

9- Clara: He's just not the kind, loving, tender guy I loved 3 years ago. Something has changed about him.

10- Laura: like?

11- Clara: He's starting to be stiff, bossy, you know, angry all the time.

12- Laura: Why don't you ask him what's wrong?

13- Clara: No good. It won't work. Things are just so messed up between us. We don't seem to click anymore. 


\section{Adult Egyptian Speakers}

\section{Conversation (7)}

1- Amira: Jaklik mitdaaji? fi haaga hâșâlit walla Peeh

"You look upset. Did anything go wrong?"

2- Suzy: Pembaarih lamma Samalt Pelıada medhat

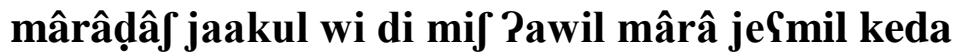

"Yesterday, when I cooked lunch, Medhat refused to eat, and this isn't the first time he does this."

3- Amira: leeh da kaan dajman bejheb tâbii iik

"Why? He always liked your cooking"

4- Suzy: Pajwa bas Pommu gat Paৎadit Yandena fâhr kaamil wi min waPtaha taṣârofato Petıâjârit wi maba?aaj fi haaga PaSmelha teSgebu

"Yes but his mother stayed in our place for a whole month, and since then his attitude changed and he started to dislike anything I do."

5- Amira: Peeh Pelkalaam da Pentu Pelli jeJofku majePolf Pin ba?alku set siniin mitgawiziin tâșârofatku kaanit zaj Pelৎariis wi Pelৎaruusa jeẓhâr Penoku Pethasadu 
"What's this talk? Whoever sees you wouldn't ever think that you've been married for six years. You always behaved like a bride and a bridegroom. It seems you've been envied."

6- Suzy: la hasad wala haaga Pomu hejja sabab kol Pelmafaakil di Jiṭ̂ân ha?i?ii

"It's not envy or anything. His mom is the cause of all problems. She's a real devil."

7- Amira: Pizaaj

"How?"

8- Suzy: mabâțâlif nâqd lil?akl wi tanḍiifi lilbeet wi Jorli hatta dalaGi liwlaadi mif Gagibha

"She kept criticizing everything; my cooking, cleaning of the house, and my job. She didn't even like the way I pamper my kids."

9- Amira: Seeb Salehaa

"Shame on her"

10- Suzy: we tisada?i bit?olu howwa Pelli beteSmelu da Pakl walla da tanḍiff hejja leeh bitftaral di Samlak dada lamma teruuh ?elforl 
"And she tells him 'Is this food? Is this cleaning? Why does she work? She makes you a babysitter when she goes to work.' Can you believe it?"

11- Amira: mâjṣâhið te?uul keda

"She shouldn't say this."

12- Suzy: wi kamaan bit?olu Peni Pafat Sala Pelkorsi wi râfâft regli Yala Peltarâbeeza fi weJha

"She also tells him that I sat on the chair and put my leg on the table before her face."

13- Amira: wi da kalaam had jesada?u di keda betwa Pa beenik wi beenu wi betexreb ?elbeet

"Nobody would believe this talk. She's driving a wedge between you and your husband and destroying the house."

14- Suzy: Safaan keda rabena masabhaa

"Because of this, God punished her."

15- Amira: Pizzaj

"How?"

16- Suzy: wi hejja țâlfâ Pelsellim fi betha wa?aßit wi regleeha ?etqâsârit 
"While she was going up the stairs in her house, she fell and broke her leg."

17- Amira: ?âlâhomma laa Jamaata bas da Yeqââb râbena liiha

"O God! No schadenfreude but this is God's punishment to her."

18- Suzy: ९ârâfit texda؟ Pelkol

"She knew how to deceive everybody."

19- Amira: șâhiih kaanit tebaan țâjeba bas țâlâYit

"True. She seemed to be kind but turned out to

be $["$

20- Suzy: bas țalâfit Jâșejja bafißa rabena jekfiiki fârrâha wi fâ Pamsalha

"but turned out to be a horrible person. May God protect you from her wickedness and the wickedness of her likes."

\section{Conversation (8)}

1- Dr. Ayman: Pembaarih Peldoktoor mehamad Samal mawqif makontif ?ataðajjal ?enu jeৎmelu 
"Yesterday Dr. Mohamed did something I never thought he would do."

2- Dr. Yehia: Pelha?ii?a Pelli Samalu fi maglis Pelkolleja PelPosbuuf Pelli faat kefaaja

"Actually, what he did in the faculty council meeting last week is enough."

3- Dr. Ayman: la? Gamal mâwqif taani małaaja Pana Jâșejan kont lessa badi? mohâḍ̂reti wi fag?a la?eet doktoor mehamad bijxâbât falajja wije?olli ?enni waaxid Pelqâfâ betaStu

"No, he did another thing with me personally. I was just starting my lecture and suddenly the door knocked and it was Dr. Mohamed telling me that I've taken his hall."

4- Dr. Yehia: Pizzaj hejja mi qâfâât Pelmohâḍârâât metwazaYa Sala Pel?âqsaam min Pawil Pelterm howwa dajman keda $\chi$ aalif toSraf

"How is that? Aren't the lecture halls distributed among the departments from the beginning of the term? He always acts differently from others."

5- Dr. Ayman: belzâât keda

"Exactly" 
6- Dr. Yehia: wi Gamalt Peeh

"And what did you do?"

7- Dr. Ayman: Poltelu Pin Pelqâfâ betaSti binaaPan Sala tawzii PelqâYâât Pelli Pettafa?at Yaleeh kol PelPâqsaam fi PelPigtemå Pelli Samalu wikiil Pelkolleja lefo?uun Pelțollâb wi Pin qesmu howwa Pelqesm Pelwahiid Pelli mahâḍ̂ary momasiliin Cannu

"I told him that the hall is mine according to the distribution that was decided upon by all the departments in the meeting held by the vice dean for students' affairs. I also told him that his department was the only one from which there were no representatives in the meeting."

8- Dr. Yehia: țâbৎân Pelkalaam da majeৎgaebhuu

"Of course, he wouldn't like this talk."

9- Dr. Ayman: tââân la?

"Of course not."

10- Dr. Yehia: wi kaan Peeh râd fẹlu

"And what was his reaction?"

11- Dr. Ayman: Palli Penu maaji Sala Peltawzii Pelli mâḍ̂a Yaleeh PelSamiid Pabl keda 
"He told me that he is following the distribution that the dean signed before."

12- Dr. Yehia: da fâxṣ mostafiz Peltawzii PelPadiim da mif moqâddâs wi momkin jetuâjjâr

"He's a provocative person. The old distribution is not holy and can be changed."

13- Dr. Ayman: ma Pana lamma Poltelu Pin Peltawziiß Petsâjjâr la?etu bij\}uul lelțâlâbâ bituưu Po?afu Poddaam maktab wikiil Pelkolleja lefo?uun Pelțollââb wi Pef̣̣âlu waPfiin hinaak lehad ma jehel Pelmojkela wi law Peljoom Pentaha min seer Pelmofkela tethal hanaxod Pelmohâḍ̂â PelPosbuuf Pelgaj filțor?a Pelli Poddam Pilqâfâ betaYetna

"When I told him that the distribution has changed, he told his students to go and stand in front of the office of the vice dean for students' affairs and to remain standing there till the problem is solved, and if, by the end of the day, the problem is not solved, they'll take the lecture in the corridor in front of the hall."

14- Dr. Yehia: Peeh da tâhriị̣ șâriih da Pakiid

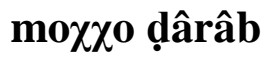


"What? This is clear instigation. He must have lost his mind."

15- Dr. Ayman: bijetẓââhir bePenu Jâxṣ sawragi wi bejdâwwâr fala ha?u Paw Pelli howwa fakir Penu ha?u

"He pretends to be a rebellious person who is looking for his right or rather what he thinks is his right."

16- Dr. Yehia: besâḍ Pelnâzâr fan kono ha?u Paw mif ha?u howwa mif Saarif ?in Postaaz ?ilgamৎa qodwa

"Regardless of what is or is not his right. Doesn't he know that a university professor is an example?"

17- Dr. Ayman: da majefrâff haaga fan Pelqodwa wi Pelqejam Pelgamefejja

"He knows nothing about exemplary behavior and university values."

18- Dr. Yehia: Seeb Pawi Pelli Yamalu da

"What he did is so disgraceful."

19- Dr. Ayman: râbena jehdi

"May God grant him guidance." 


\section{Conversation (9)}

1-Ashraf: bada?t Pagahez feluus Pelderuus

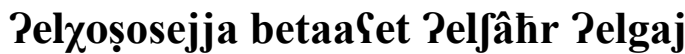

"I started to prepare the money for next month's private lessons".

2- Samar: tâab Pefmel hesaabak Pin misțâr mahmuud modarres Pelৎârâbi Saajez jedi magmuuৎet Pahmad heșâs zejaada Pelfâhr Pelgaj

"Ok, take into consideration that mister Mahmoud, the Arabic teacher, wants to give Ahmed's group extra lessons next month."

3- Ashraf: taani Pelrââgel da zaj Pelmoknesa PelqâhrâbaYeja kol Jowajja jeffoṭ feluus

"Again! This man is like a vacuum cleaner; he absorbs money every now and then."

4- Samar: la? mif kol Jowajja

"No, not every now and then."

5- Ashraf: howwa mif Samal keda Pelfâhr Pelli faat "Didn't he do so last month?

6- Samar: Pelfâhr Pelli faat Pahmad Paxad heșâṣ zejaada fi PelPengliizi Pelfâhr Pelgaj baPolak misțâr 
mahmuud modarres Pelfârâbi howwa Pelli Saajez jedi Pelwelaad heṣ̂ạ zejaada

"Last month, Ahmed took extra lessons in English. I'm telling you next month Mr. Mahmoud, the Arabic teacher, is the one who wants to give the kids extra lessons."

7- Ashraf: wi leeh heșâs zejaada mif ?ahmad maafi kowajjes fi Pelৎârâbi

"Why the need for extra lessons? Isn't Ahmed doing fine in Arabic?"

8- Samar: bij\}uul Pin Peltâlâbâ fi magmuuYet Pahmad mostawaahom ḍ̂Âiif wi mehtagiin jetmârânu zejaada

"He says that students in Ahmed's group are weak and need to practice more."

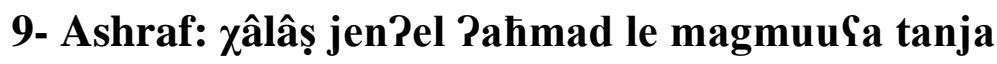
mostawaaha Pahsan min Pelmagmuufa Pelli howwa fiiha

"Then tell him to move Ahmed to another group that's better than the one he's in now." 


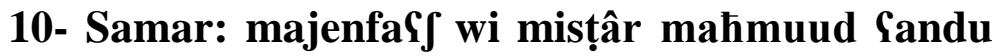

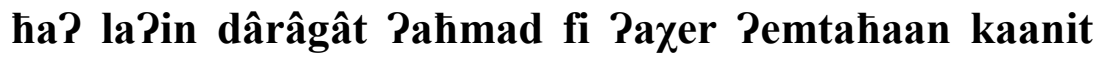
wehfa

"This won't do and Mr. Mahmoud is right because Ahmed got a bad mark in the last test."

11- Ashraf: howwa laazim jegiib Peldârâgâ Pelneha?ejja Salafaan mostawaa majeb?aa đ̣̂âiif wi biṣârâhâ Pelmodarres da Pisterlaali

"Must he get the full mark so as not to be considered weak? And frankly, this teacher is a profiteer."

12- Samar: bas howwa Jâațer wi Gaajez jehasin mostawa ?ahmad mif la?enu bijhebu wa ?enama la?inu hâriiṣ Pin țâlâbtu jegiibu dârâgâât Salja fi PelPemtahaan Yafaan jehââfiz Yala somৎetu kamodarres

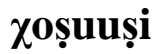

"But he's clever and wants to improve Ahmed's level not because he likes him but because he's keen on making his students get high marks in the final exam as he wants to keep his reputation as a private teacher."

13- Ashraf: Pana mif mowaf?ik Pelrââgil da nâsââb kol fowajja jeSmel Pemtahanaat wi jeddi 
Pelțâlâbâ dârâgâât ḍâfiiifa wi je?uul lil?ahaali Pin weladhom mehtagiin heșâṣ zejaada

"I don't agree. This guy is a swindler; every now and then he examines the students, gives them bad marks and tells the parents that their kids need extra lessons."

14- Samar: da mif șâhiih Pelli bijehșâl Pin fi țalâbâ bitgiib dârâgâât ḍ̂âiiifa bas kamaan fi bigiibu dârâgâât kowajjesa ?awi

"This is not true. What happens is that some kids get weak marks but there are also those who get very good marks."

15- Ashraf: kaam țââlib Pakiid Yadad ṣosâjjâr

"How many students? A small number for sure.

16- Samar: Pelmodarres da somfetu mesamafa wi Pelmohim Pin fi țâlâbâ bitgiibu fi Pemtahanatu dârâgâât kowajjesa wi bitgiib fi PelPimtahaan Pelnehaa?i kamaan dârâgâât Yalja gidan

"This teacher has a good reputation. What matters is that there are students who get good marks in his tests and also get very high marks in the final exam." 
17- Ashraf: ?enti methamesaalu gidan ka?in mafiif modarres zaju ma Pelmodaresiin Pelkowajjesiin kitiir

"You're an ardent supporter of him as if there's no teacher like him. There are so many good teachers."

18- Samar: Pelmodaresiin Pelkowajjesiin kitiir bas Pelmodarres da somৎetu kowajjesa Pawi wi baSdeen Penta motahaamil faleeh gidan

"There are so many good teachers but this one has a very good reputation. You're not fair to the guy."

19- Ashraf: la?eni Jaajef Penu Pintehaazi wi bijazod feluus kitiir

"Because I believe he's an opportunist and takes a lot of money."

20- Samar: Pelhamdolila Penena Padriin nedfas Pelmohim Pelnatiiga

"Thank god we can afford it. The result is what matters."

21- Ashraf: wi natiiget Penu bijoffot Pelfeluus min Pelțâlâbâ Penu raakib Sârâbejja gidiida Pahdas haaga 
"And the result of absorbing money from the students is that he has a new car that's of the latest model."

22- Samar: ?elParzaa? di min râbena

"Blessings are from God."

23- Ashraf: Penti kol Pelli jehemek Pin Pelwalad jaxod Pelheșâṣ Pelzejaada

"All what matters to you is that the boy takes the extra lessons."

24- Samar: Safaan Yajza mâșlâhtu

"Because I want what is good for him."

\section{Adult Native English Speakers}

Conversation (10)

1- Lesley: Are you still thinking about Dorothy?

2- Margaret: Yeah, she's been through too much at such an early age. Poor thing!

3- Lesley: Well, she's the one to blame. What could a woman like in a man like Steve? I just don't get it. He was a real misfit. 
4- Margaret: True. Personally, I always thought so and never actually liked him.

5- Lesley: But you never said anything. Don't you think that's strange?

6- Margaret: No, I couldn't have said anything coz she loved him, but I always noticed he was so arrogant and showy and untrustworthy.

7- Lesley: That's what I don't understand. He's not even attractive, you know, his scruffy hair, shabby clothes, everything everything.

8- Margaret: Believe it or not, that's what she liked about him and she always told me he's the sort of man most women would go for, and that he's so handsome and hot and different.

9- Lesley: Well, he is different. And does she still think he's hot after all what she's been through and after the divorce?

10- Margaret: She just can't stand him and she's like "Oh God, why did I do this?" She keeps regretting getting married to this miser guy.

11- Lesley: But has he always been miser? I mean, is this how he was like when she first got to know him? 
12- Margret: I guess so but love is blind, you know.

13- Lesley: yeah and how was it like after he left his job?

14- Margaret: Gosh! Things just got worse. They quarreled all the time and he started to beat her and took her money and being his mother's [

15- Lesley:

[spoiled brat

16- Margaret: Exactly

17- Lesley: I'm really sorry for Dorothy.

\section{Conversation (11)}

1- Kate: Goodness, that's a beautiful place. I love it.

2- Freddie: Yeah, me too and the people are very kind.

3- Kate: Not all of them. The seller in the first bazaar is a bit too greedy.

4- Freddie: Don't pass judgments so easily. He was nice and friendly.

5- Kate: I'm saying what I think. The statue of King Tut was so expensive and it was a small statue. 
6- Freddie: But the prices of the other stuff in the bazaar were ok.

7- Kate: I don't see this.

8- Freddie: And I don't see that his prices are very different from those of the sellers in the other bazaars.

9- Kate: Even if they aren't very different, his prices are still higher and to me this makes him greedy.

10- Freddie: Calm down, we didn't buy anything from him anyway.

11- Kate: Because he was so hard-headed and wouldn't cut down the price of anything we wanted to buy.

12- Freddie: But he was welcoming.

13- Kate: No, he wasn't genuine. He's a clever actor.

14- Freddie: He's a clever guy and was simply trying to sell us some souvenirs.

15- Kate: You mean he was trying to force us to buy some exceptionally expensive and not very special souvenirs. You are easily deceived by appearances. 
16- Freddie: Not true, my dear. I just take things easy. You're taking it too hard.

17- Kate: You didn't see his nasty reaction when we walked away without buying anything.

18- Freddie: What did he do?

19- Kate: He changed his seemingly nice way of treating tourists and pulled a face and murmured and pouted.

20- Freddie: That's rude.

21- Kate: So you're starting to agree

22- Freddie: of course.

23- Kate: and apart from his expensive prices, he doesn't have enough variety.

24- Freddie: You're right. His shop is a bit small and there isn't a lot of varieties.

25- Kate: Thanks!

Conversation (12)

1- Jackie: You look so upset. What's the matter?

2- Barbara: Well, I'm worried about Mark. 
3- Jackie: Yeah, I can understand.

4- Barbara: He just can't cope with his father's loss.

5- Jackie: Poor thing! He loved him so much and was so close to him.

6- Barbara: And he can't believe he's gone forever, and it's starting to affect him badly.

7- Jackie: I know he was so down and had such a bleak view about life.

8- Barbara: And he wouldn't speak to anybody. That's why I thought of coming to Egypt, you know, just to try to help him get out of this mood. I know how much he loves Egypt.

9- Jackie: That's a good idea and I can see he's enjoying the trip.

10- Barbara: But before we came here, his teacher told me he started to be aggressive and rude with the other kids in school.

11- Jackie: What? That's bad and it's very unlike him. He's becoming a troublemaker.

12- Barbara: I don't know what to do. 
13- Jackie: Why don't you make him see a psychiatrist?

14- Barbara: I suppose you're right. 